Flora Huang and Horace Yeung*

\title{
Law-Finance-Growth Nexus in the Context of Africa
}

https://doi.org/10.1515/ldr-2018-0028

\begin{abstract}
This article seeks to put the law-finance-growth nexus into the context of Africa. As of 2017, the African Securities Exchanges Association has 27 securities exchanges as full members. The Johannesburg Stock Exchange is the most developed of all, especially with respect to its market capitalization. Its socio-legal proximity with the English system may provide a good explanation to its phenomenal growth relative to the rest in the region. However, such a socio-legal proximity is indeed shared by a number of other former British colonies such as Nigeria and Zimbabwe. Law alone may not account for the rise of the Johannesburg Stock Exchange. Furthermore, this article seeks to argue whether there is a genuine need for the African countries to have a stock market, which requires highly evolved legal, market and governmental institutions and norms that often do not pre-exist in these countries. On the one hand, the article will look at Africa in general. On the other hand, it will put certain discussions into the context of selected African countries.
\end{abstract}

Keywords: Africa, institutions, economic development, law, finance

\section{Introduction}

Institutional economics, which has existed for nearly 100 years, is a branch of scholarship which explores the role of institutions in economic activities and growth. Different types of institutions have been reviewed by scholars, including but not limited to finance, ${ }^{1}$ law, ${ }^{2}$

\footnotetext{
1 See, for example, J. Schumpeter, The Theory of Economic Development (Cambridge: Harvard University Press, 1959); R. McKinnon, Money and Capital in Economic Development (Washington, DC: Brookings, 1973); R. King and R. Levine, Finance and Growth: Schumpeter Might Be Right, 108 Quarterly Journal of Economics, no. 3 (1993), 717-737; and see Section 2.1.

2 See, for example, F. Modigliani and E. Perotti, Protection of Minority Interest and the Development of Security Markets, 18 Managerial and Decision Economics, no. 7-8 (1994), 519-528; T. Beck and R. Levine, "Legal Institutions and Financial Development", in
}

*Corresponding author: Horace Yeung, Leicester Law School, University of Leicester, Leicester LE1 7RH, UK, E-mail: horace.yeung@leicester.ac.uk

Flora Huang, School of Law, University of Essex, Colchester CO4 3SQ, UK,

E-mail: flora.huang@essex.ac.uk 
politics, ${ }^{3}$ trade, ${ }^{4}$ culture, ${ }^{5}$ technology, ${ }^{6}$ education, ${ }^{7}$ colonial origin, ${ }^{8}$ etc. These institutions are not stand-alone but are interlinked. For example, a country legal system is normally dependent on its colonial origin. ${ }^{9}$ For the relationship between law, finance and growth, the explanation can be that law helps deepening the financial markets, thereby facilitating economic growth. ${ }^{10}$ Allen and colleagues have famously put the law, finance and growth nexus into the context of China. ${ }^{11}$ They argued that China represents an important counterexample to the wider law, institutions, finance and growth literatures: neither legal nor financial system was well developed, yet it has been one of the fastest growing economies. This article seeks to add to the debate by putting the same nexus into the context of Africa.

This article will look at Africa in general as a continent. At the same time, certain African countries are selected for further analysis in key sections. The countries selected are the Seychelles, South Africa, Morocco and Egypt. The Seychelles is important as it is the only high-income country in Africa according to the World Bank. On the other hand, South Africa, Morocco and Egypt house the three largest stock markets in the region. This article will consider the role of finance and law in the economic development of these countries, together with

C. Menard and M. Shirley (eds.), Handbook of New Institutional Economics (Dordrecht: Springer, 2005); and see Section 2.2 below.

3 See, for example, A. Przeworski and F. Limongi, Political Regimes and Economic Growth, 7 Journal of Economic Perspectives, no. 3 (1993), 51-69; and R. Barro, Determinants of Democracy, 107 Journal of Political Economy, no. 6 (1999), 158-183.

4 See, for example, D. Acemoglu and J. Ventura, The World Income Distribution, 107 Quarterly Journal of Economics, no. 2 (2002), 659-694.

5 See, for example, W. Easterly and R. Levine, Africa's Growth Tragedy: Policies and Ethnic Divisions, 112 Quarterly Journal of Economics, no. 4 (1997), 1203-1250.

6 See, for example, E. Bartelsman and M. Doms, Understanding Productivity: Lessons from Longitudinal Microdata, 38 Journal of Economic Literature, no. 3 (2000), 569-594.

7 See, for example, N. G. Mankiw, D. Romer and D. Weil, A Contribution to the Empirics of Economic Growth, 107 Quarterly Journal of Economics, no. 2 (1992), 407-437.

8 See, for example, D. Acemoglu, S. Johnson and J. Robinson, The Colonial Origins of Comparative Development: An Empirical Investigation, 91 American Economic Review, no. 5 (2001), 1369-1401.

9 See, for example, D. Klerman et al., Legal Origin or Colonial History?, 3 Journal of Legal Analysis, no. 2 (2011), 379-409.

10 R. Levine, Law, Finance, and Economic Growth, 8 Journal of Financial Intermediation, no. 1-2 (1999), 8-35.

11 F. Allen, J. Qian and M. Qian, Law, Finance, and Economic Growth in China, 77 Journal of Financial Economics, no. 1 (2005), 57-116. 
Africa as a whole. This article is divided into three sections. The next section will flesh out the theoretical foundation of discussion by drawing on the existing debate about the importance of institutions, particularly in light of finance and law, respectively. Then, it will proceed to discuss the finance-growth nexus in the context of Africa, before doing the same for the law-finance nexus. At the end, the conclusion will seek to link up all the dots by summarizing how the findings about Africa in this article can provide any insights into the debate on the relationship between law, finance and growth.

\section{Institutions and economic growth}

The study of institutions can be traced back to as early as 1899 when Veblen said:

The evolution of social structure has been a process of natural selection of institutions. The progress which has been and is being made in human institutions and in human character may be set down, broadly, to a natural selection of the fittest habits of thought and to a process of enforced adaptation of individuals to an environment which has progressively changed with the growth of the community and with the changing institutions under which men have lived. ${ }^{12}$

Hamilton further claimed that "the proper subject-matter of economic theory is institutions" and coined the term "institutional economics," which concerns how the institutions shape economic behavior. ${ }^{13}$ This has planted the seed of the more recent development in the research of the role of institutions in economic development. ${ }^{14}$ According to Acemoglu and colleagues, economists and historians have long emphasized the importance of institutions. ${ }^{15}$ The institutions' hypothesis alleges that societies with a social organization

12 T. Veblen, The Theory of the Leisure Class: An Economic Study of Institutions (New York: Macmillan 1899), p. 87, available at: <http://moglen.law.columbia.edu/LCS/theoryleisureclass. pdf>, accessed 26 March 2018.

13 W. Hamilton, The Institutional Approach to Economic Theory, 9 American Economic Review, no. 1 (1919), 309-318. See also G. Hodgson, What is the Essence of Institutional Economics?, 34 Journal of Economic Issues, no. 2 (2000), 317-329.

14 M. Rutherford, Institutional Economics: Then and Now, 15 Journal of Economic Perspectives, no. 3 (2001), 173-194, at 187.

15 D. Acemoglu, S. Johnson and J. Robinson, Reversal of Fortune: Geography and Institutions in the Making of the Modern World Income Distribution, 117 Quarterly Journal of Economics, no. 4 (2002), 1231-1294, at 1262. 
that provides encouragement for investment will prosper. This new movement of institutional economics has generally identified itself as an attempt to extend the range of neoclassical theory by explaining the institutional factors traditionally taken as givens, such as property rights and governance structures. ${ }^{16}$ Yet it is not easy to give "institutions" a precise definition. As put by North, "Institutions are the rules of the game in a society or, more formally, are the humanly devised constrains that shape human interaction." ${ }^{17}$ Whilst saying that "there is no unanimity in the definition of this concept [of institution]," Hodgson tries to define institutions as "systems of established and prevalent social rules that structure social interactions" and thus "language, money, law, systems of weights and measures, table manners, and firms (and other organizations)" are all institutions. ${ }^{18}$ Such a broad definition clearly adds to the complexity of what matters for economic development.

\subsection{Finance as a type of institution}

Acemoglu stresses the importance of economic institutions, which comprise such things as the structure of property rights, the presence of markets and the contractual opportunities available to individuals and companies. ${ }^{19}$ Take stock market as an example. The primary role of a stock market is the allocation of ownership of the economy's capital stock. ${ }^{20}$ The market is a developed system which creates more information about investment projects and can therefore guide investors' funds to better uses. ${ }^{21}$ Specialization, as well as acquisition and dissemination of information, is encouraged to reduce the cost of aggregating dispersed savings, thereby facilitating investment. ${ }^{22}$

16 Rutherford (2001), supra note 14.

17 D. North, Institutions, Institutional Change and Economic Performance (Cambridge: CUP, 1990), p. 3.

18 See G. Hodgson, What Are Institutions?, 40 Journal of Economic Issues, no. 1 (2006), 1-25, at 2 .

19 D. Acemoglu, Introduction to Modern Economic Growth (Princeton: Princeton University Press, 2009) p. 120.

20 E. Fama, Efficient Capital Markets: A Review of Theory and Empirical Work, 25 Journal of Finance, no. 2 (1970), 383-417.

21 R. Atje and B. Jovanovic, Stock Markets and Development, 37 European Economic Review, no. 2-3 (1993), 632-640.

22 P. Arestis, P. Demetriades and K. Luintel, Financial Development and Economic Growth: The Role of Stock Markets, 33 Journal of Money, Credit and Banking, no. 1 (2001), 16-41, at 18. 
The market is often viewed as the most efficient allocation of capital in some cases because of the shortcomings of bank finance. In the presence of asymmetric information, banks generally finance only well-established, safe borrowers, while stock markets can encourage more risky, productive and innovative projects. ${ }^{23}$ Furthermore, equity markets allow companies to rely more on equity and less on debt, creating a less risky financial structure in the event of an economic downturn. ${ }^{24}$ On the other hand, investors are generally reluctant to relinquish control of their savings for long periods, despite the fact that many high-return projects require a long-term commitment of capital. A liquid stock market can enable more investment to occur because savers can buy and sell quickly and cheaply whenever they wish to alter their portfolios, especially with the development of technology. ${ }^{25}$ Moreover, stock markets provide a vehicle for investors to diversify risk. ${ }^{26}$ With a diversified investment portfolio, investors may shift part of their savings into higher-return projects, which can influence economic growth. Such growth can also come from the mitigation of agency cost because corporate control is enhanced through stock markets. ${ }^{27}$

To illustrate the importance of stock markets, some scholars have tried to examine the empirical relationship between stock markets and economic growth. A cross-sectional study of 39 countries over the period 1980-1988, by Atje and Jovanovic, has suggested that the relative size of a country's stock

23 G. Caporale, P. Howells and A. Soliman, Stock Market Development and Economic Growth: The Causal Linkage, 29 Journal of Economic Development, no. 1 (2004), 33-50, at 36. For example, many markets have junior boards, often with lower listing requirements, to help growth enterprises raise capital. Also, venture capitalists are often the financiers for new start-ups. Stock markets provide these venture capitalists with an exit strategy. It is argued that there is a link between the stock market and the venture capital market. See, for example, B. Black and R. Gilson, Does Venture Capital Require an Active Stock Market?, 11 Journal of Applied Corporate Finance, no. 4 (1999), 36-48.

24 S. Claessens, S. Djankov and D. Klingebiel, "Stock Markets in Transition Economies” (2000), Financial Sector Discussion Paper No. 5, available at: <http://ssrn.com/abstract=240703>, accessed 26 March 2018.

25 R. Levine and S. Zervos, Stock Market Development and Long-Run Growth, 10 World Bank Economic Review, no. 2 (1996), 323-339, at 326.

26 Ibid., p. 327.

27 A. Demirguc-Kunt and R. Levine, Stock Markets, Corporate Finance and Economic Growth: An Overview, 10 World Bank Economic Review, no. 2 (1996), 223-239, at 231. Although a diffuse ownership structure will reduce the incentives for investors to monitor the management carefully, the countervailing argument is that a remuneration package tied to stock performance and takeover threats are possible ways to align the interests of managers and owners. Also, the presence of institutional investors and securities analysts can potentially enhance monitoring. 
market helps to explain subsequent growth in gross domestic product (GDP) per capita. ${ }^{28}$ Building on Atje and Jovanovic's study, Levine and Zervos have subsequently confirmed that there is a strong correlation between overall stock market development and long-term economic growth. ${ }^{29}$ However, in contrast to the supporting opinions, Harris has found no hard evidence that the level of stock market activity helps to explain growth in per capita output. ${ }^{30}$ Despite the debates, Carlin and Mayer are quite right to say that very little is known about the way in which financial structures bear on economic performance. ${ }^{31}$ The studies have been restricted to assessments of whether there is a link between financial and economic performance. They have failed to address the range of other questions that lie at the heart of debates about financial systems; for example, the effect of corporate and legal structures. Policies concerning the structure of financial and corporate systems should be sensitive to different stages of economic development. ${ }^{32}$ There is no such thing as one size fits all.

\subsection{Law as a type of institution}

Why do different countries have different financial systems? Are these different financial systems performing different functions? Can we say that one system is better than another? In the Anglo-American system, financial markets play an important role in allocating resources, while in Germany and other continental systems they are relatively unimportant (see Chart 1). Despite the apparent divergence, as observed by Allen and Gale, the current trend is towards the market-based systems. ${ }^{33}$ Many countries have deliberately tried to deepen their financial markets. Nevertheless, the development of a strong securities market is by no means automatic. As discussed, if property rights and governance structures, or more generally investor protection, are the determining factors, then company law, securities law, listing rules and other institutional factors are all

28 Atje and Jovanovic (1993), supra note 21.

29 Levine and Zervos (1996), supra note 25, p. 327.

30 R. Harris, Stock Markets and Development: A Re-assessment, 41 European Economic Review, no. 1 (1997), 139-146. This study covered 49 of the 80 countries that had official stock markets in 1991 and spanned the period 1980-1991.

31 W. Carlin and C. Mayer, Finance, Investment and Growth, 69 Journal of Financial Economics, no. 1 (2003), 191-226.

32 Ibid., p. 193.

33 F. Allen and D. Gale, Comparing Financial Systems (Cambridge: MIT Press, 2000), p. 5. 
relevant. Unfortunately, these structures depend upon highly evolved legal, market and governmental institutions and norms that often do not pre-exist in a new market. ${ }^{34}$

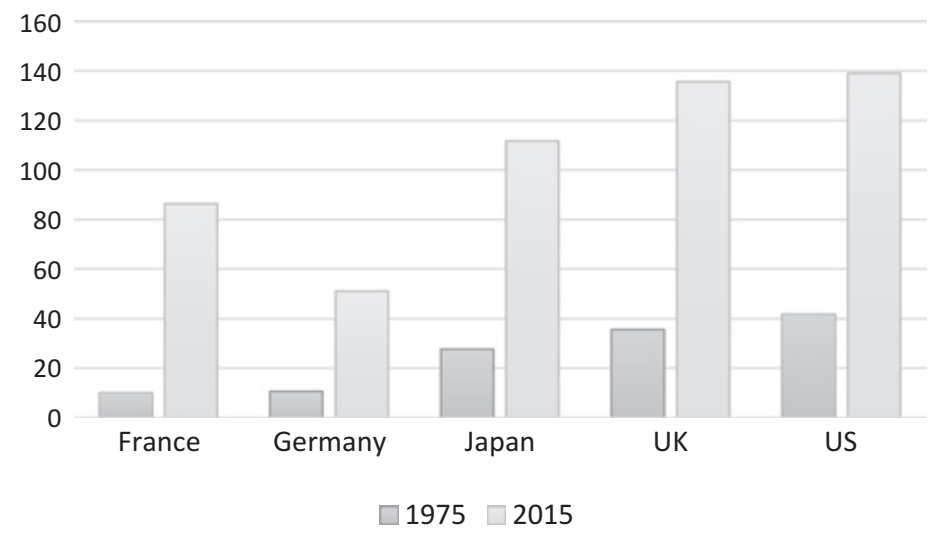

Chart 1: Market Capitalization of Listed Domestic Companies in Selected Countries (\% of GDP). Source: World Bank, with compilation of the 2015 data of the UK by the author.

Lee criticizes that the relationship between law and economic and social progress is relatively unknown and underdeveloped as an academic field despite decades of research. ${ }^{35}$ La Porta and colleagues have examined legal rules covering the protection of corporate shareholders and creditors, the origin of these rules and the quality of their enforcement in 49 countries. $^{36}$ They have alleged that the legal

34 B. Black, The Legal and Institutional Preconditions for Strong Securities Markets, 48 UCLA Law Review, no. 4 (2001), 781-855.

35 Y. Lee, General Theory of Law and Development, 50 Cornell International Law Journal, no. 3 (2017), 415-471. Examples of past research, as unearthed by Lee, include D. Trubek and M. Galanter, Scholars in Self-Estrangement: Some Reflections on the Crisis in Law and Development Studies in the United States, Wisconsin Law Review (1974), 1062-1103; F. Snyder, The Failure of Law and Development, Wisconsin Law Review (1982), 373-396; B. Tamanaha, The Lessons of Law-and-Development Studies, 89 American Journal of International Law, no. 2 (1995), 470-486; R. Posner, Creating a Legal Framework for Economic Development, 13 World Bank Observer, no. 1 (1998), 1-11; K. Dam, The Law-Growth Nexus (Washington, DC: Brookings, 2006); and D. Trubek, “Law and Development 50 Years On (2012)", University of Wisconsin Legal Studies Research Paper no. 1212, available at: <http://ssrn.com/abstract=2161899>, accessed 26 March 2018.

36 R. La Porta et al., Legal Determinants of External Finance, 52 Journal of Finance, no. 3 (1997), 1131-1150; R. La Porta et al., Law and Finance, 106 Journal of Political Economy, no. 6 (1998), 1113-1155; R. La Porta et al., Investor Protection and Corporate Governance, 58 Journal of Financial Economics, no. 1-2 (2000), 3-27; and R. La Porta, F. Lopez-de-Silanes and A. Shleifer, What Works in Securities Laws?, 61 Journal of Finance, no. 1 (2006), 1-32. 
environment, including both legal rules and their enforcement, matters for the size and extent of a country's capital market. It is because a good legal environment protects the potential financiers against expropriation by entrepreneurs. Investors are willing to surrender funds in exchange for securities and therefore expand the scope of capital markets. Based on their findings, they have claimed that French civil law countries with the weakest investor protection have smaller and narrower capital markets. ${ }^{37}$ Such classification using legal families, with little regard to each particular country's "demand for law" in the first place, later attracted criticisms from other scholars. ${ }^{38}$ Furthermore, Spamann criticizes that many of the initial results from La Porta and colleagues are not robust to the correction of coding errors. ${ }^{39}$ Legal rules differ across many relevant dimensions, in particular in international comparison. It is simply very difficult to draw the lines in each of them by variable definitions. As suggested by Siems, it is overly simplistic to examine how different legal families shape finance. ${ }^{40}$ Furthermore, the causal link between the rise of dispersed ownership, strong shareholder protection and the development of stock markets may not be apparent. ${ }^{41}$ They convincingly coexist. In addition to the empirical evidence by La Porta and colleagues, as observed by Black, a "strong markets" equilibrium works in the following way:

Strong investor protection produces high prices, which encourage honest companies to issue shares. This increases share prices and encourages more honest issuers to issue shares. Outside investors then generate political support for strong investor protection. ${ }^{42}$

In contrast to La Porta and others' account, Coffee and Cheffins have shown in the UK and the US the opposite sequence that financial markets developed first, and

37 Ibid.

38 See for example, D. Berkowitz, K. Pistor and J. Richard, Economic Development, Legality and the Transplant Effect, 47 European Economic Review, no. 1 (2003), 165-195 and M. Siems, Legal Origins: Reconciling Law \& Finance and Comparative Law, 52 McGill Law Journal, no. 1 (2007), 55-81. A mere categorization of a system as common law or civil law disregards deeper legal structures. La Porta and colleagues subsequently attempt a unified interpretation and address several objections to the empirical claim that legal origins matter. See R. La Porta, F. Lopez-de-Silanes and A. Shleifer, The Economic Consequences of Legal Origins, 46 Journal of Economic Literature, no. 2 (2008), 285-332.

39 H. Spamann, The "Antidirector Rights Index" Revisited, 23 Review of Financial Studies, no. 2 (2010), 467-486.

40 Siems (2007), supra note 38.

41 J. Coffee, The Rise of Dispersed Ownership The Roles of Law and the State in the Separation of Ownership and Control, 111 Yale Law Journal, no. 1 (2001), 1-82; B. Cheffins, Does Law Matter?: The Separation of Ownership and Control in the United Kingdom, 30 Journal of Legal Studies, no. 2 (2001), 459-484; and M. Roe, Legal Origins, Politics and Modern Stock Markets, 120 Harvard Law Review, no. 2 (2006), 460-527.

42 Black (2001), supra note 34, p. 784. 
then created a political demand for investor protection. ${ }^{43}$ Further, as indicated by Dam, securities markets did blossom in the US and the UK in the nineteenth and early twentieth centuries before modern securities regulation was introduced. ${ }^{44}$ Unfortunately, the unregulated markets were vulnerable to various forms of manipulation and abuse. As a result, in the US, Federal intervention in the 1930s by introducing the Securities Act of 1933 and the Securities Exchange Act of 1934 was justified by a contention of market failure. ${ }^{45}$ To improve on La Porta and colleagues' research design, by using time-series dataset, John Armour and colleagues find no evidence of a positive impact of legal changes on stock market development, despite agreeing that common law systems were more protective of shareholder interests than civil law ones. ${ }^{46}$ Despite that the conclusion from where "law matters" is far from clear, the study by La Porta and colleagues has phenomenally started a new branch of legal scholarship known as "Law and Finance," which seeks to unearth the correlations between law and financial development. ${ }^{47}$ We seek to contribute to this field by studying the law-finance-growth nexus in the context of Africa through this article.

\section{Aligning economic and financial development in Africa}

The economic development in Africa has been admittedly slow when compared to what has been witnessed on other continents (except Antarctica). Various economic benchmarks are able to illustrate this fact. The World Bank has classified its 189 member countries, ${ }^{48}$ and all other economies with populations

43 See Coffee (2001), supra note 41, pp. 65-66; and Cheffins (2001), supra note 41, pp. 483-484. 44 Dam (2006), supra note 35, pp. 188-189.

45 R. Romano, Empowering Investors: A Market Approach to Securities Regulation, 107 Yale Law Journal, no. 8 (1998), 2359-2430, at 2367. The framework of securities legislation in the US consists of seven related but separate statutes that are administered by the Securities and Exchange Commission.

46 J. Armour et al., Shareholder Protection and Stock Market Development: An Empirical Test of the Legal Origins Hypothesis, 6 Journal of Empirical Legal Studies, no. 2 (2009) 343-380.

47 Siems (2007), supra note 38, p. 57.

48 The World Bank recognizes 48 economies in their Sub-Saharan Africa grouping, together with six countries in their Middle East and North Africa grouping, making up the total number of African countries (54). See more from World Bank, World Bank Country and Lending Groups (2017), available at: <https://datahelpdesk.worldbank.org/knowledgebase/articles/906519-world-bank-country-andlending-groups>, accessed 26 March 2018. Likewise, the United Nations recognizes 54 countries in their African Group of Member States, see United Nations, United Nations Regional Groups of Member States (2017), available at: <http://www.un.org/depts/DGACM/RegionalGroups.shtml>. 
Table 1: Categories of African countries by international organizations in 2017.

\begin{tabular}{llrrr}
\hline Category & $\begin{array}{r}\text { Total number of } \\
\text { economies }\end{array}$ & $\begin{array}{r}\text { Number in } \\
\text { Africa }\end{array}$ & $\begin{array}{r}\text { \% in } \\
\text { Africa }\end{array}$ \\
\hline World Bank & High-income economies & 79 & 1 & 1.2 \\
& $\begin{array}{l}\text { Upper-middle-income } \\
\text { economies }\end{array}$ & 56 & 9 & 16 \\
& Lower-middle-income- & & & \\
& economies & 52 & & 32.7 \\
& Low-income economies & 31 & 27 & 87.1 \\
United Nations & Least developed countries & 47 & 33 & 70.2 \\
\hline
\end{tabular}

Sources: World Bank and United Nations.

of more than 30,000 into several notable groups. ${ }^{49}$ As seen in Table 1, as of 2017, out of 79 high-income economies, only one is in Africa, which is the Seychelles. The Seychelles was moved to this group recently in 2015. ${ }^{50}$ But note the Gross National Income (GNI) per capita of the country in that year was US $\$ 14,680$, well below the average of US\$1,932 in that group. We start to see some African economies when we move down a category to the upper-middle-income group and more and more of them towards the bottom of the categories. When we look at the list of least developed countries (LDCs), compiled by the UN, we find that all are low-income countries confronting severe structural impediments to sustainable development. ${ }^{51}$ They are regarded by the UN as highly vulnerable to economic and environmental shocks and have low levels of human assets. The list is reviewed every 3 years by the Committee for Development of the UN. As of June 2017, there are currently 47 countries on the list of LDCs. ${ }^{52}$ Of which, 33 of

49 The groups, divided according to 2015 gross national income (GNI) per capita, are low income, US $\$ 1,025$ or less; lower middle income, US $\$ 1,026-4,035$; upper middle income, US\$4,036-12,475; and high income, US\$12,476 or more.

50 Department of Foreign Affairs of the Seychelles, Seychelles Graduates to High-Income Country Status according to World Bank Standards (2015), available at: <http://www.mfa.gov. sc/static.php?content_id=18\&news_id=1071>, accessed 26 March 2018.

51 Three indicators selected as criteria to classify countries as LDCs are: (1) GDP per capita, which gives a general indication of the dimensions of poverty and overall level of development; (2) the share of manufacturing in GDP, which conveys information on the extent of structural transformation of the economy and (3) adult literacy rate, which specifies the size of the base for enlarging a skilled labour force.

52 United Nations Committee for Development Policy, List of Least Developed Countries (as of June 2017) (2017), available at: <https://www.un.org/development/desa/dpad/wp-content/ uploads/sites/45/publication/ldc_list.pdf>, accessed 26 March 2018. 
them are from Africa. The most recent country off the list (from the original 48) was Equatorial Guinea on 4 June 2017. ${ }^{53}$ Apart from very low levels of per capita income which indicate severe financial constraints, the sole criterion used by the World Bank in its categorization, the Committee for Development identified other common features among the LDCs. ${ }^{54}$

- Dominance of agriculture or primary activities in the generation of GDP and the absorption of the labour force; predominance of subsistence activities (accompanied by limited capacity for mobilizing domestic resources) with low levels of labour productivity, particularly in food production;

- Limited manufacturing and an undiversified production structure reflected in high export concentration and dependence on two or three primary commodities, and high volatility of export earnings (upon which fiscal revenues rely); LDCs therefore are unable to benefit from trade measures for manufacturers unless these measures are accompanied by support to stimulate industrial production and diversification;

- Low level of education and an overall shortage of skills to organize and manage development; limited capacity to absorb technological advances; poor health and nutrition outcomes;

- Lack of adequate physical and institutional infrastructure for development;

- Economically small (by population or national income), undiversified natural resource base.

Former UN Secretary General Kofi Annan once said 67\% of all problems dealt with by the UN were African problems. ${ }^{55}$ In April 1998, as a response to a request from the UN Security Council, he presented a report, entitled "The Causes of Conflict and the Promotion of Durable Peace and Sustainable Development in Africa," to discuss the origins of Africa's political and economic problems and characterize the situation at that point. ${ }^{56}$ He rightly pointed out that the framework of colonial laws and institutions which African states inherited following a decolonization movement had been designed to exploit local divisions, but not

53 General Assembly Resolution A/RES/68/18 adopted on 4 December 2013, decided that Equatorial Guinea would be taken off the list three and a half years after the adoption of the resolution, i. e. on 4 June 2017.

54 United Nations, Handbook on the Least Developed Country Category: Inclusion, Graduation and Special Support Measures (New York: United Nations, 2015), pp. 2-3.

55 BBC, Is Kofi Annan Pulling his Weight for Africa? (2000), available at: <http://news.bbc.co. uk/1/hi/talking_point/debates/african/677098.stm>, accessed 26 March 2018.

56 United Nations, Secretary-General's Report on the Causes of Conflict and the Promotion of Durable Peace and Sustainable Development in Africa, Report A/52/871-S/1998/318 (1998). 
overcome them. ${ }^{57}$ On the issue of economic growth, Annan emphasized the need of "creating a positive environment for investment" to produce sustained economic growth. ${ }^{58}$ The measures suggested in the report were roughly coinciding with the study of institutions discussed above, which proposedly include "predictable policies, economic deregulation, openness to trade, rationalized tax structures, adequate infrastructure, transparency and accountability, and protection of property rights." 59

Infrastructure here in the report predominantly pointed to the likes of transport, telecommunications and schools, but the importance of legal institutions and economic infrastructures was also briefly mentioned. In the context of this article, Allen and colleagues criticize that Africa as a continent has been most underdeveloped in terms of finance. ${ }^{60}$ In general, the banking sector in Africa is much shallower and less penetrated than those in other major regions of the world, as evidenced by a common indicator of financial deepening, i. e. domestic credit to the private sector as a percentage of GDP (see Chart 2). Meanwhile, there have been some positive developments. First, there has been an increasing presence of foreign banks in the region, apparently indicating an increasing degree of openness of the

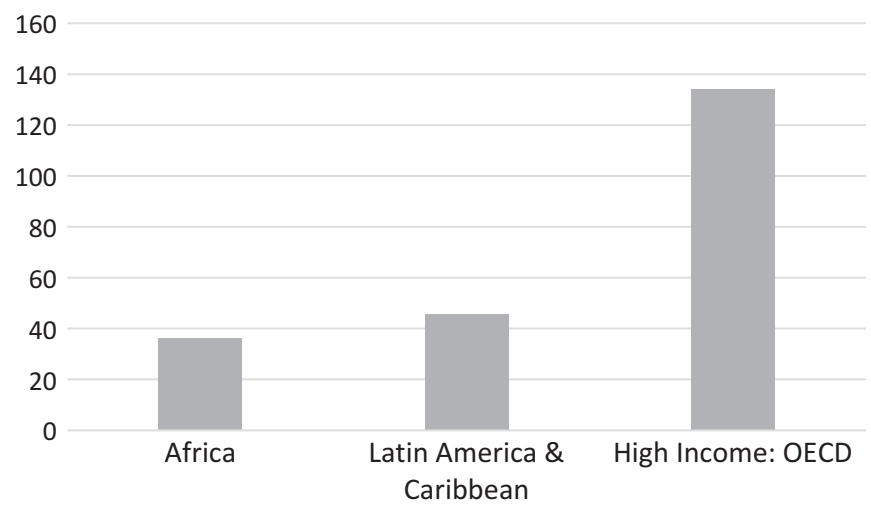

Chart 2: Domestic Credit to the Private Sector as a Percentage of GDP in Selected Regions in 2014.

Source: E. Nyantakyi and M. Sy, The Banking System in Africa: Main Facts and Challenges, 6 Africa Economic Brief, no. 5 (2015), 1-16, p. 3.

57 Ibid., para. 8.

58 Ibid., para. 81.

59 Ibid.

60 F. Allen, I. Otchere and L. Senbet, African Financial Systems: A Review, 1 Review of Development Finance, no. 2 (2011), 79-113. 
financial sector, as well as investor confidence in the region. ${ }^{61}$ Second, Allen and colleagues particularly point out the highly sophisticated banking system of the Seychelles as one "similar to that found in most developed countries." 62 This view clearly sits well with the economy's status as a high-income economy as defined by the World Bank, the only one in Africa.

With respect to stock markets, since its foundation in 1993, the African Stock Exchanges Association (ASEA) has promoted not only the development of stock exchanges, but also cooperation among them. As of June 2017 the Association is represented by 27 Exchanges serving 32 African countries. ${ }^{63}$ Almost all stock exchanges in Africa are members of the ASEA, with the exceptions of Somalia ${ }^{64}$ and Algeria, ${ }^{65}$ as well as the second and younger exchanges in countries such as Nigeria ${ }^{66}$ and Uganda. ${ }^{67}$ The number of stock exchanges in the region has been rising quite steadily over the years with 6 in 1989, 19 in 2000 and slightly more than 30 nowadays. ${ }^{68}$ The oldest one is the Egyptian Exchange in Cairo which traced its origins to 1883 when the Alexandria Stock Exchange was established, closely followed by the Johannesburg Stock Exchange (JSE) in South Africa

61 Ibid., p. 80 and S. Claessens et al., "Foreign Bank Presence in Developing Countries 1995-2006: Data and Trends (2008)", World Bank Working Paper, available at: <https://ssrn.com/abstract= 1107295>, accessed 26 March 2018.

62 Allen et al. (2011), supra note 60, p. 107.

63 ASEA, Membership: Introduction (2017), available at: <http://www.african-exchanges.org/ en/membership\#contentCarousel/introduction>, accessed 26 March 2018.

64 The Somali Stock Exchange is the first ever stock exchange to operate in Somalia. The Exchange began selling its first shares in on 1 September 2015 at the exchange's headquarters in Garowe, Somalia. See Somali Stock Exchange, About Us (2017), available at: <http://www. somalistockexchange.so/about-us>, accessed 26 March 2018.

65 The Algerian Stock Exchange (SGBV Bourse d'Algérie in French) in Algiers was launched for trading in July 1999. See Algerian Stock Exchange, SGBV (2017), available at: <http://www.sgbv. dz/?page=rubrique\&lang=eng\&mod=116>, accessed 26 March 2018.

66 The main stock exchange in Nigeria, the Nigerian Stock Exchange, located in Lagos, was founded in 1960, and is a founding member of the ASEA. In contrast, Abuja Securities \& Commodity Exchange was established in 1998 and is based in Abuja, Nigeria. See Nigerian Stock Exchange, Corporate Overview (2017), available at: <http://www.nse.com.ng/about-us/ about-the-nse/corporate-overview>and the website of the Abuja bourse is available at: <http:// www.abujacomex.com>, both accessed 26 March 2018.

67 The national stock exchange, the Uganda Securities Exchange, was founded in 1997. Its younger counterpart, ALTX East Africa Exchange, was created in 2014. Both are located in Uganda's capital, Kampala. See Uganda Securities Exchange, Background (2017), available at: $<$ https://www.use.or.ug/content/background>and ALTX East Africa Exchange, About Us (2017), available at: <https://www.altxafrica.com/about-altx>, both accessed 26 March 2018.

68 J. Irving, Africa's Struggling Stock Exchanges, 14 Africa Recovery, no. 3 (2000), 25-28. 
which was formed in $1887 .{ }^{69}$ Not only is the JSE one of the oldest, it is also the largest bourse in the region and is currently ranked the 19th largest in the world by market capitalization. ${ }^{70}$ In Bank of America Merrill Lynch's survey of the world markets, the US, with a market capitalization of US\$17.9 trillion, is the biggest and represents $53.4 \%$ of the total size of the markets in the world..$^{71}$ The next largest equity markets are Japan, UK, France, Switzerland, Germany, China and Australia. Markets in Africa and South America are comparatively and notably far less vibrant.

On the other hand, considering that there are 54 African countries and there are only some 30 stock exchanges on the continent, there must be a number of these countries which do not have a stock exchange. According to the investigation by Investment Frontier in July 2014, of the roughly 200 nations (both official and partially recognized) in the world, 40 of these countries did not have a stock exchange. ${ }^{72}$ A number of them were in Africa, especially the more populated ones. It is worth noting that Ethiopia, with a population of 88 million, is the largest country in the world without a stock exchange. ${ }^{73}$ In contrast, even with a population of merely 93,186, the Seychelles still has its own stock exchange, Trop-X. ${ }^{74}$ Since 2014, some of those 40 countries have already launched an exchange or planned to launch one, such as Somalia and Angola. ${ }^{75}$ Furthermore, it is worth noting that Regional Securities Exchange (Bourse Régionale des Valeurs Mobilières, in short BRVM) and Centrale Africa Stock Exchange (Bourse des valeurs Mobilières de l'Afrique Centrale, in short BVMAC)

69 Egyptian Stock Exchange, History (2017), available at: <http://www.egx.com.eg/english/ History.aspx>and Johannesburg Stock Exchange, JSE Overview (2017), available at: <https:// www.jse.co.za/about/history-company-overview>, both accessed 26 March 2018.

70 Johannesburg Stock Exchange (2017), supra note 69.

71 BofA Merrill Lynch, Transforming World Atlas (2016), available at: <https://www.bofaml. com/content/dam/boamlimages/documents/articles/ID16-305/bofaml_transforming_world_ atlas_2nd_edition.pdf>, accessed 26 March 2018.

72 Investment Frontier, List of Countries without Stock Exchanges (2014), available at: <https:// www.investmentfrontier.com/2014/07/28/list-countries-without-stock-exchanges>, accessed 26 March 2018.

73 African Leadership Magazine, Ethiopia: Largest Country in the World without a Stock Exchange (2015), available at: <http://africanleadership.co.uk/ethiopia-largest-country-in-theworld-without-a-stock-exchange>, accessed 26 March 2018.

74 The website of Trop-X is available at: <https://www.trop-X.com>.

75 See supra note 64, and see Agencia Angola Press, Angola Stock Exchange may play strategic role in SADC (2017), available at: <http://www.angop.ao/angola/en_us/noticias/economia/2017/ 2/11/Angola-Stock-Exchange-may-play-strategic-role-SADC,f9423b85-4a9c-4008-951a0674cb75d222.html>, accessed 26 March 2018. 
Table 2: African stock exchanges according to market cap at 31 December 2016.

\begin{tabular}{ll}
\hline >US\$100 bn & Soutd Africa \\
US\$30-100 bn & Egypt, and Morocco \\
US\$6-30 bn & BRVM (Benin, Burkina Faso, Côte d'Ivoire, Guinea-Bissau, Mali, Niger, \\
& Senegal and Togo), Kenya, Nigeria, and Tunisia \\
US\$1-6 bn & Botswana, Ghana, Namibia, Tanzania, Uganda, Zambia, and Zimbabwe \\
Other active & Algeria, BVMAC (Central African Republic, Chad, Equatorial Guinea, Gabon, \\
exchanges & and Republic of Congo), Cameroon, Cape Verde, Libya, Malawi, Mauritius, \\
& Mozambique, Rwanda, Seychelles, Somalia, Sudan, and Swaziland \\
Inactive/No & Angola, Burundi, Comoros, Democratic Republic of Congo, Djibouti, \\
exchange & Eritrea, Ethiopia, Gambia, Guinea, Lesotho, Liberia, Madagascar, \\
& Mauritania, Sao Tome and Principe, Sierra Leone, and South Sudan \\
\hline
\end{tabular}

Source: PwC, 2016 Africa Capital Markets Watch (2017), available at: <https://www.pwc.co.za/ en/assets/pdf/africa-capital-markets-watch-2016.pdf>, accessed 26 March 2018.

are organized to serve multiple countries. ${ }^{76}$ Table 2 provides a snapshot of the African stock exchanges as of the end of 2016. We will proceed to look the story of selected countries below.

\subsection{The Seychelles}

As mentioned before, in July 2015, the Seychelles reached high-income status, after average GNI per capita reached US\$13,710 in 2013-2014. It is the only African country which has made such an achievement. According to the African Development Bank, the country experienced robust economic growth during the period averaging 5.3\% in 2011 to 2015, with the traditional tourism and fisheries sectors as the main drivers of economy. ${ }^{77}$ Poverty rates in Seychelles are amongst the lowest in the world outside the OECD countries. ${ }^{78}$ Despite being praised by Allen

76 BRVM, located in Abidjan, Cote d'Ivoire, which began trading in 1998, is organized to serve eight countries: Benin, Burkina Faso, Guinea Bissau, Cote d'Ivoire, Mali, Niger, Senegal and Togo. Their website is at<http://www.brvm.org $>$. BVMAC, located in Libreville, Gabon, is organized to serve five countries: The Central African Republic, Chad, Congo, Equatorial Guinea and Gabon. Their website is available at: 〈http://www.bvm-ac.com>.

77 African Development Bank, Seychelles Economic Outlook (2017), available at: <https:// www.afdb.org/en/countries/east-africa/seychelles/seychelles-economic-outlook/>, accessed 26 March 2018.

78 World Bank, Seychelles: Overview (2017), available at: <http://www.worldbank.org/en/coun try/seychelles/overview>, accessed 26 March 2018. 
and colleagues as having a sophisticated banking system comparable to the most developed world, the IMF identified certain shortcomings of the system in $2000 .^{79}$ First, there was very limited bank lending to the private sector, compared with other countries at a similar level of development. Second, the sector was dominated by state-owned financial institutions. Third, there was excess liquidity in the banking system and limited demand for credit. However, at that time, the system was essentially sound and profitable with non-performing loans below $5 \%$ of loans outstanding for all banks. ${ }^{80}$ Nowadays, as observed and pointed out by Allen and colleagues, most Seychellois have access to their own bank accounts, automatic teller machines, credit and debit cards. ${ }^{81}$ All types of accounts are available including current, fixed deposits, call deposits, savings schemes and loan accounts, and all major credit cards are represented. As reported by the Central Bank of Seychelles, there has certainly been a year-on-year increase in the demand for loans, especially in key economic sectors (see Table 3). As shown in Table 3, a

Table 3: Loans and advances to various economic sectors in the Seychelles.

\begin{tabular}{lrrrrr}
\hline In Seychellois rupee million) & $\mathbf{2 0 1 2}$ & $\mathbf{2 0 1 3}$ & $\mathbf{2 0 1 4}$ & $\mathbf{2 0 1 5}$ & $\mathbf{2 0 1 6}$ \\
\hline Total advances & $3,280.5$ & $3,428.3$ & $4,311.7$ & $4,645.7$ & $5,122.7$ \\
of which: Foreign Currency Loan & 655.2 & 646.4 & $1,124.1$ & $1,163.7$ & $1,174.0$ \\
Agriculture and Horticulture & 20.1 & 17.5 & 31.8 & 49.6 & 61.5 \\
Fisheries & 17.3 & 15.0 & 37.4 & 52.1 & 44.9 \\
Manufacturing & 37.5 & 33.8 & 57.0 & 102.3 & 184.2 \\
Real Estate & 310.2 & 423.3 & 564.8 & 649.7 & 636.5 \\
Construction & 294.8 & 388.1 & 341.8 & 376.1 & 444.0 \\
Transportation & 119.1 & 179.7 & 165.5 & 177.9 & 172.5 \\
Tourism Facilities & 689.0 & 548.9 & 930.8 & 986.1 & 959.7 \\
Wholesale and Retail Trade & 186.2 & 202.4 & 338.6 & 404.9 & 495.9 \\
Financial Institutions & $\mathrm{n} . \mathrm{a}$. & $\mathrm{n} . \mathrm{a}$. & 4.7 & 2.0 & 0.9 \\
Other Business & 514.1 & 403.4 & 410.9 & 343.6 & 447.6 \\
Private Households and Non-profit & 664.7 & 763.4 & 947.7 & 998.3 & $1,096.5$ \\
$\quad$ Organizations & & & & & \\
Mortgage Loans & 427.6 & 452.8 & 480.7 & 503.0 & 578.4 \\
\hline
\end{tabular}

Source: Central Bank of Seychelles, Annual Report 2016 (2017), available at: <http://www.cbs. sc/Downloads/publications/Annual\%20Report\%202016.pdf>, accessed 26 March 2018.

79 IMF, Seychelles: Recent Economic Developments, Country Report No. 00/162 (2000), para. 32, available at: <https://www.imf.org/external/pubs/ft/scr/2000/cr00162.pdf >, accessed 26 March 2018.

80 Ibid., para. 35.

81 Allen et al. (2011), supra note 60, p. 107. 
substantial proportion of outstanding loans has always gone to the tourism sector. Furthermore, there has been a notable fourfold increase in loans to the manufacturing sector, demonstrating a growing shift of the economy to production. Meanwhile, stock market is not a major landscape in the allocation of national capital. As of May 2017, the domestic exchange Trop-X has 10 listed companies only, with a total market capitalization of US $\$ 11.1$ million (as a comparison, just $0.001 \%$, $0.018 \%$ and $0.03 \%$ of the size of the Johannesburg Stock Exchange, Bourse de Casablanca and the Egyptian Exchange, the top three exchanges in Africa). ${ }^{82}$

\subsection{South Africa}

According to the categorization of the World Bank, South Africa is just an upper-middle-income economy. ${ }^{83}$ Its economic performance struggled recently with GDP growth declined from 1.5\% in 2014 to 1.3\% in 2015, with further weakening expected. ${ }^{84}$ The South African economy moved into recession with the reported decrease of $0.7 \%$ in GDP during the first quarter of 2017, following a $0.3 \%$ contraction in the fourth quarter of $2016 .{ }^{85}$ The African Development Bank indicates that electricity shortages, low commodity prices and low consumer and business confidence continue to restrain the growth of economic activity. ${ }^{86}$ Historically, South Africa's economy was primarily built on primary and secondary industries, such as mining and manufacturing, but in recent decades, in line with global developments, growth has shifted to the tertiary industries. ${ }^{87}$ Currently, industries that contribute to the economy include finance, real estate and business services, manufacturing and wholesale and retail trade. Unemployment remains one of the key challenges faced by South Africa. The unemployment rate increased to $27.7 \%$ in the first quarter of 2017 ,

82 Data from the World Federation of Exchanges.

83 Other African countries in the group include Algeria, Angola, Botswana, Equatorial Guinea, Gabon, Libya, Mauritius and Namibia.

84 African Development Bank, South Africa Economic Outlook (2017), available at: <https:// www.afdb.org/en/countries/southern-africa/south-africa/south-africa-economic-outlook/>, accessed 26 March 2018.

85 Statistics South Africa, The South African Economy Shrinks by 0.7\% (2017), available at: <http://www.statssa.gov.za/?p=9989>, accessed 26 March 2018.

86 African Development Bank (2017), supra note 84.

87 Statistics South Africa, The Economy of South Africa (2017), available at: <http://www. statssa.gov.za/?page_id=595>, accessed 26 March 2018. 
the highest since $2003 .{ }^{88}$ In the face of the uncertain economic outlook and the resulting weakening of the South African government's credit profile, Moody's downgraded the credit rating of South Africa's top five banks in 2017. ${ }^{89}$ At the same time, Moody's also downgraded 10 South African regional and local governments and three development finance institutions. Shortly before that, Fitch and Standard and Poor's, the other two main global ratings agencies, had already downgraded South Africa to junk status. ${ }^{90}$ Despite recent ratings downgrades, South Africa still has a well-developed banking system. South African banks hold the first six places among the top 100 banks on the African continent. ${ }^{91}$ Four large banks dominate, with Standard Bank of South Africa, Nedbank, ABSA (Amalgamated Bank of South Africa, now owned by Barclays) and FirstRand Bank collectively accounting for around 85\% of banking services in South Africa. At the same time, there are approximately 70 foreign banks operating in South Africa. ${ }^{92}$

Along with a well-developed banking system, there is the largest stock market in Africa. As of May 2017, the Johannesburg Stock Exchange had a market capitalization of US $\$ 1$ trillion, around 10 times the size of the Bourse de Casablanca and the Egyptian Exchange combined, which are already the second and third largest exchanges on the continent. ${ }^{93}$ The JSE was founded on 8 November $1887 . .^{94}$ The Stock Exchange Control Act, which was the first legislation covering financial markets, was promulgated in 1947. The JSE joined the World Federation of Exchanges in 1963 and in 1993 it became a founder member of the ASEA. The JSE was demutualized and incorporated in South Africa as the JSE Limited (a public unlisted company) on 1 July 2005, and then listed on its own exchange the next year. Nowadays, as of May 2017, there are 375 listed companies on the exchange. Some of these are global corporate giants such as

88 A. Gumede and A. Mbatha, The Charts That Show South Africa's Unemployment Problem (2017), available at: <https://www.bloomberg.com/news/articles/2017-06-01/south-africa-job less-rate-rises-to-14-year-high-in-first-quarter>, accessed 26 March 2018.

89 Moody's, Moody's Downgrades the Five Largest South African Banks to Baa3; Outlook Negative (2017), available at: <https://www.moodys.com/research/Moodys-downgrades-thefive-largest-South-African-banks-to-Baa3-PR_367888>, accessed 26 March 2018.

90 J. Cotterill, "Fitch Cuts South Africa's Credit Rating to Junk”, Financial Times, 7 April 2017. 91 Department of Commerce US, South Africa - Banking Systems (2016), available at: <https:// www.export.gov/article?id=South-Africa-banking-systems>, accessed 26 March 2018.

92 Ibid.

93 Data from the World Federation of Exchanges.

94 Johannesburg Stock Exchange (2017), supra note 69. 
BHP Billiton, British American Tobacco and SAB Miller. ${ }^{95}$ It is worth noting that for BHP Billiton and British American Tobacco, their presence in JSE may be merely one of their multiple listings around the world. However, for the case of SAB Miller, it does have a South African root, with SAB actually standing for South African Breweries. As mentioned before, the JSE is currently ranked the 19th largest in the world by market capitalization. Located in the most vibrant market in Africa, the JSE is starting to face some new competition. ZAR X, selfdescribed as "a low-cost, simple and convenient trading platform that empowers ordinary South Africans with shareholdership opportunities," and the 4 Africa Exchange, backed by one of South Africa's richest black families, the Maponya Group, both were granted a license by the Financial Services Board of South Africa in 2016 to start trading. ${ }^{96}$ Furthermore, there were three applications under the Financial Markets Act for licensed exchanges in 2016 including AX2, YPN Exchange and the Equity Express Stock Exchange. According to Rossouw, indeed the JSE has little to worry about in terms of competition and the competition is good for investors so as to put a limit on the ability of a monopoly stock exchange to charge inflated prices for trading and settlement services. ${ }^{97}$

\subsection{Morocco}

The World Bank has put Morocco in the lower-middle-income economic group. ${ }^{98}$ According to the African Development Bank, Morocco is posting balanced macroeconomic results, thanks to country's proactive policy of improving the business climate to help to transform its economic model. ${ }^{99}$ On the one hand,

95 For a full list, refer to Johannesburg Stock Exchange, Find an Equity Issuer (2017), available at: <https://www.jse.co.za/current-companies/companies-and-financial-instruments>, accessed 26 March 2018.

96 L. Chutel, "South Africa may Get Three more Stock Exchanges - And a lot more Investors", Quartz, 18 April 2016, available at: <https://qz.com/662054/south-africa-may-get-three-morestock-exchanges-and-a-lot-more-investors/>, accessed 26 March 2018.

97 J. Rossouw, "Why the Johannesburg Stock Exchange Knows what Rivalry is all about”, The Conversation, 31 March 2016, available at: <https://theconversation.com/why-the-johannes burg-stock-exchange-knows-what-rivalry-is-all-about-57076>, accessed 26 March 2018.

98 Other African countries in the group include Cabo Verde, Cameroon, Republic of the Congo, Côte d'Ivoire, Djibouti, Egypt, Ghana, Kenya, Lesotho, Mauritania, Nigeria, São Tomé and Principe, Sudan, Swaziland, Tunisia and Zambia.

99 African Development Bank, Morocco Economic Outlook (2017), available at: <https://www. afdb.org/en/countries/north-africa/morocco/morocco-economic-outlook/>, accessed 26 March 2018. 
major steps were taken in the legal and fiscal domains and in exchange regulations. On the other hand, major public investments are moving forward, such as the Nador West Med port, TGV high-speed train, Noor solar complex and Kenitra Atlantique port. It is worth noting that growth has relied on the agricultural sector. It was estimated that agriculture contributed to half of the 6.5\% GDP growth in 2001. ${ }^{100}$ Even in 2016, low rainfall was expected to have a strong effect on this sector, with knock-on effects for GDP growth. ${ }^{101}$ According to the IMF, Morocco's financial system is bank dominated and highly concentrated. ${ }^{102}$ Furthermore, Moroccan banks have expanded both domestically and regionally since the global financial crisis. Banks have significantly widened their range of products and services, which has led to increased bank penetration (63\% of total population now has a bank account compared to $43 \%$ in 2008). ${ }^{103}$ Also, the three largest Moroccan bank groups have expanded rapidly abroad, notably in Sub-Saharan Africa. It is worth noting that despite being an Islamic country, Morocco did not have an Islamic financial institution until very recently. The first Islamic bank in Morocco, Umnia Bank, opened its doors in 2017 after the country's central bank finally approved requests to open Islamic financial institutions in the beginning of the year. ${ }^{104}$ On the other hand, Morocco has a sizable stock market, which is the second largest in Africa. Bourse de Casablanca was established in 1929. As of May 2017, the bourse had a market capitalization of US $\$ 60$ billion, with 75 listed companies. ${ }^{105}$ It is dominated by large banks and telecommunication firms. ${ }^{106}$ Finance, telecommunication and construction firms account for nearly $70 \%$ of total capitalization; the three largest banks alone account for $30 \%$. Despite the fact that it is already the second largest stock market in Africa, Bourse de Casablanca was downgraded to "frontier market" status from "emerging market" by index provider MSCI in 2013, due to lack of market liquidity. ${ }^{107}$ To revive the market, Morocco's

100 African Development Bank and OECD, African Economic Outlook (Abidjan: African Development Bank And OECD 2003), p. 219, available at: <https://www.oecd.org/countries/ morocco/2497527.pdf>, accessed 26 March 2018.

101 African Development Bank (2017), supra note 99.

102 IMF, Morocco: Financial System Stability Assessment, Country Report No. 16/37 (2016), available at: <https://www.imf.org/en/Publications/CR/Issues/2016/12/31/Morocco-FinancialSystem-Stability-Assessment-43676>, accessed 26 March 2018.

103 Ibid.

104 Reuters, Morocco Opens First Islamic Bank Branch Months after Approval (2017), available at: 〈http://www.reuters.com/article/morocco-banks-idUSL8N1IP6CO〉, accessed 26 March 2018. 105 Data from the World Federation of Exchanges.

106 IMF (2016), supra note 102.

107 Reuters, Moroccan Government Drafts New Rules to Attract Stock Market Investors (2015), available at: <http://www.reuters.com/article/morocco-market-idUSL5N11H29220150911>, 
government was planning to allow foreign companies to list on the Casablanca stock exchange and creating a second market dedicated to small- and mediumsized businesses. ${ }^{108}$ On accommodating foreign issuers, clearly Bourse de Casablanca has not acted as quick as the JSE. ${ }^{109}$ Since 2004, foreign firms have been allowed to list on the JSE, subject to foreign exchange rules, which limited the amount of these equities that local investors could hold. In 2011, further reform was witnessed to alter South Africa's listing rules, allowing foreign domiciled companies to be treated as domestic listings. The lifting of these restrictions may provide one good explanation as to why the JSE is leading in Africa, but not its counterparts like Bourse de Casablanca.

\subsection{Egypt}

Egypt is categorized as a lower-middle-income economy by the World Bank along with Morocco. Despite a lengthy political transition following President Mubarak's removal from office in 2011, the African Development Bank is cautiously optimistic about Egypt's economic outlook largely owing to the government's ability to deliver on its policy reforms and growth strategy. ${ }^{110}$ Egypt's antiquities are not only part of its cultural heritage, but also represent an important economic asset that creates jobs and income. Tourism has historically accounted for about 13\% of the Egyptian economy and a corresponding amount of employment. ${ }^{111}$ Unfortunately, tourism performance has weakened amidst prolonged political instability and high threat of terrorism. Various investment projects, like the establishment of a space program in 2016, are regarded as one

accessed 26 March 2018. According to the Financial Times, Frontier market is a type of emerging market, which is considered to have lower market capitalization and less liquidity than many emerging markets. Financial Times, Definition of Frontier Markets (2017), available at: <http://lexicon.ft.com/Term?term=frontier-markets\&mhq5j=e2>, accessed 26 March 2018. As of May 2017, South Africa and Egypt are the only African countries in the Emerging Markets Group. In the Frontier Markets group, there are Morocco, along with seven other countries plus the West African Economic and Monetary Union. No African market is currently in the top tier, the Developed Markets group. MSCI, Market Classification (2017), available at: <https://www.msci.com/market-classification>, accessed 26 March 2018.

108 Reuters (2015), supra note 107.

109 Johannesburg Stock Exchange (2017), supra note 69.

110 African Development Bank, Egypt Economic Outlook (2017), available at: <https://www. afdb.org/en/countries/north-africa/egypt/egypt-economic-outlook/>, accessed 26 March 2018.

111 US Aid, Egypt: Economic Growth and Tourism (2016), available at: <https://www.usaid.gov/ egypt/economic-growth-and-tourism>, accessed 26 March 2018. 
of the moves by the government to buoy its economy, plug the financial gap caused by a huge drop in tourism and survive a foreign exchange crisis. ${ }^{112}$ According to the investigation by the World Bank in 2006, banking played a central role in Egypt's financial system, accounting for more than $60 \%$ of financial assets. ${ }^{113}$ The Egyptian banking system currently consists of 40 banks. The National Bank of Egypt, Bank Misr and Banque Du Caire are large public sector banks which control $40 \%$ of the banking sector. ${ }^{114}$ Domestic credit to private sector in 2015 was $26.5 \%$ of the GDP, around the level of the Seychelles (24.2\%), but much lower than Morocco (64.3\%) and South Africa (148.7\%), indicating low level of financial resources provided to the private sector by financial institutions. ${ }^{115}$ Generally, it is believed that the higher the financial resources or financing flowing to the private sector in a country is, the greater is the prospective opportunity for the private sector to develop and grow. At the same time, it has a smaller stock market than Morocco and South Africa, it is prudent to say that Egypt does not have the same financial depth of the two countries. For a quick comparison of the countries discussed, see Table 4. As mentioned, the Egyptian Stock Exchange is one of the oldest in the region.

Table 4: Selected economic and financial indicators of the countries discussed.

\begin{tabular}{lrrrr}
\hline & Seychelles & $\begin{array}{r}\text { South } \\
\text { Africa }\end{array}$ & Morocco & Egypt \\
\hline $\begin{array}{l}\text { GNI per capita (2015, US\$) } \\
\begin{array}{l}\text { Domestic credit to private sector as \% of GDP } \\
\quad(2015)\end{array}\end{array}$ & 14,680 & 6,080 & 3,030 & 3,340 \\
$\begin{array}{l}\text { Market cap of Domestic Stock Exchange (2017, } \\
\quad \text { US\$ million) }\end{array}$ & 11.1 & 148.7 & 64.3 & 26.5 \\
\begin{tabular}{l} 
Market cap as \% of 2015 GDP \\
\hline
\end{tabular} & 0.77 & 338.47 & 59.74 & 11.35 \\
\hline
\end{tabular}

Sources: World Bank and World Federation of Exchanges.

112 R. Michaelson, "Egypt's Economy is in Crisis. So Why is the Government Spending Millions on a Fancy New Space Agency?”, Newsweek, 28 February 2017, available at: <http://www. newsweek.com/2017/03/10/egypts-economy-crisis-government-spending-millions-new-spaceagency-561743.html>, accessed 26 March 2018.

113 World Bank, Access to Finance and Economic Growth in Egypt (Washington, DC: World Bank, 2010), available at: <http://siteresources.worldbank.org/INTEGYPT/Resources/Access_to_ Finance.pdf $>$, accessed 26 March 2018.

114 Department of Commerce US, Egypt - Banking Systems (2017), available at: <https://www. export.gov/article?id=Egypt-Banking-Systems>, accessed 26 March 2018.

115 Data from the World Bank. 
In July 1961, when the state-sanctioned demise of Egypt's private sector came, the Cairo \& Alexandria Bourses (the predecessors of the Egyptian Stock Exchange and had already merged) was the fourth largest in the world. ${ }^{116}$ Nowadays, despite being smaller than Bourse de Casablanca, it has a larger number of listed companies (254 as opposed to 75) as well as more vibrant trading, and as a result is on the MSCI's Emerging Markets list together with the JSE. ${ }^{117}$

\section{Law-finance nexus in Africa}

The market as an invisible hand guides participants in well-functioning market economies to allocate resources in ways that achieve economically efficient outcome. As discussed before, certain empirical evidence has shown that there is a positive correlation between regulation and the depth of stock market. ${ }^{118}$ Does it mean that there should be an intense degree of regulation for a market to succeed? In fact, the starting point of regulation should be that there is no need to regulate unless there is a failure of markets. ${ }^{119}$ Historically, the idea of investor protection stemmed from the risk of fraudulent or opportunity behaviour in the financial markets, making a case of a body of rules to exist to properly govern the financial markets and listed companies. ${ }^{120}$ La Porta and colleagues argue that optimal regulatory arrangements can be distilled down to three broad hypotheses. ${ }^{121}$ The very liberal approach implies that the optimal government policy is to leave securities markets unregulated because the market and some general legal mechanisms are sufficient for the markets to prosper. ${ }^{122}$ A less liberal approach suggests law is necessary owing to the consideration of enforcement costs and opportunistic behaviour of market players. One option is the standardization of the private contracting framework to improve market discipline and private litigation through securities law. Ultimately, governmental intervention may be

116 Egyptian Stock Exchange (2017), supra note 69.

117 Data from the World Federation of Exchanges; also see supra note 107.

118 See Section 2.2 of this article.

119 J. Armour et al., Principles of Financial Regulation (Oxford: OUP, 2016), p. 51.

120 J. Armour et al., Anatomy of Corporate Law (Oxford: OUP, 2017), p. 243.

121 La Porta et al. (2006), supra note 36, pp. 1-3.

122 This theory is advocated by Chicago school of economists such as Ronald Coase. In this situation, issuers of securities have an incentive to disclose all available information to obtain higher prices simply because failure to disclose would cause investors to assume the worst. Furthermore, auditors and underwriters can credibly certify the quality of securities to safeguard their reputation. 
desirable when all existing markets, legal mechanisms and private enforcement incentives are deemed insufficient. Therefore, a public enforcer is needed to support trade. Public enforcement may work because the enforcer is independent and focused. ${ }^{123}$ If regulation is necessary, two major objectives of regulation are (1) to ensure that the prices of publicly traded securities are reasonably well-informed and (2) to ensure that public shareholders are protected by effective corporate governance arrangements once they become shareholders. ${ }^{124}$

A typical regulatory system of capital market entails three tiers of regulation. ${ }^{125}$ Company law represents the bottom tier of regulation as it applies all companies, both public and private companies. Securities law represents the second tier of regulation, in that it is only relevant to companies which issue securities to the public. Listing rules represent the top tier of regulation and are relevant only to the relatively small group of companies whose securities are admitted to listing. Together, there are dedicated regulators who oversee the market. They are normally the exchanges themselves and a separate specialized public agency, such as the Securities and Exchange Commission of the US.

World Bank's Doing Business project provides the measures of business regulations and their enforcement across 190 economies. ${ }^{126}$ It covers 11 indicator sets. Amongst which, the Protecting Minority Investors indicator is perhaps the most relevant in the context of this article. The minority investor protection index measures the extent of protection from conflicts of interest and shareholders' rights in corporate governance. ${ }^{127} \mathrm{~A}$ higher index indicates a better protection of investors' interests. The maximum score is 10. OECD high-income countries on average gets a score of 6.5 in 2017. In contrast, Sub-Saharan African countries get an average score of 4.3 and the remaining six countries in North Africa get an even lower average of 3.93, lower than other regions in the world (see Chart 3).

123 See for example, H. Jackson and M. Roe, Public and Private Enforcement of Securities Laws: Resource-based Evidence, 93 Journal of Financial Economics, no. 2 (2009), 207-238; and J. Coffee, Law and the Market: The Impact of Enforcement, 156 University of Pennsylvania Law Review, no. 2 (2007), 229-312.

124 Armour et al. (2017), supra note 120, pp. 243-258. See also L. Gullifer and J. Payne, Corporate Finance Law: Principles and Policy (Oxford: Hart, 2015), p. 487.

125 I. MacNeil and A. Lau, International Corporate Regulation: Listing Rules and Overseas Companies, 50 International and Comparative Law Quarterly, no. 4 (2001), 787-810.

126 World Bank. Doing Business Report 2017 (2017), available at: <http://www.doingbusiness. org>, accessed 26 March 2018.

127 Important parameters include the extent of disclosure, director liability, shareholder rights and suits, etc. 


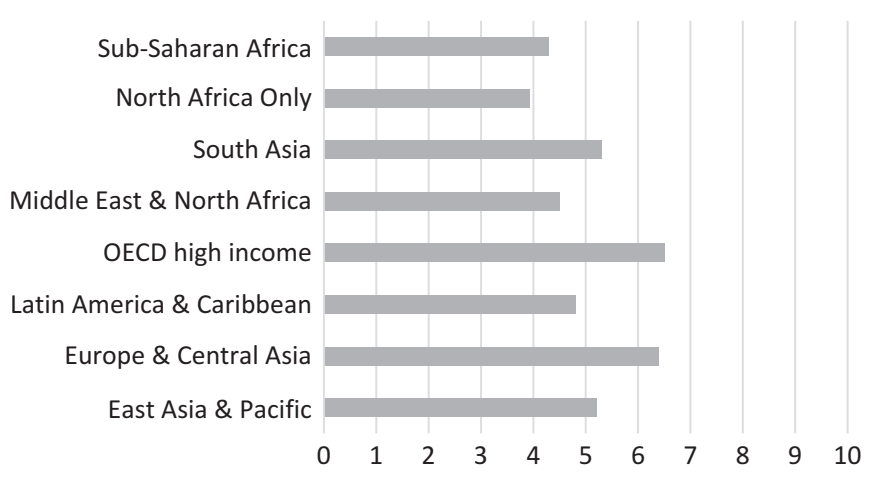

Chart 3: Shareholder Protection Index (Average Score: Max 10) in Selected Regions. Source: World Bank, Doing Business Report 2017 (2017), available at: <http://www.doingbusi ness.org>, accessed 26 March 2018.

Looking at the performance of individual countries where there is an active stock market and also available data, South Africa, with the most vibrant exchange in the region, is rightly the most protective of investors (see Table 5). Quite equally protective of investors is Nigeria. However, it only has the fourth largest stock exchange in the region with a market cap of around US $\$ 30$ billion. ${ }^{128}$ As shown by Armour and colleagues, the correlation between law and finance is far from clear. ${ }^{129}$ This is also illustrated from Table 5. The Egyptian Stock Exchange is the third largest; however, the shareholder protection index of Egypt is just 4.8, lower than almost all countries which have a shallower exchange towards the bottom of the table except Tanzania. Likewise, Morocco has a fairly respectable score of 5.3; however, this performance is still not as good as Nigeria, Botswana and Namibia, all of which again with a shallower market. But just looking at the three top performers, South Africa, Nigeria and Mauritius, it can easily be assumed that their corporate and financial regime may have a notable British root. This is largely consistent to the view that common law systems were more protective of shareholder interests than civil law ones. ${ }^{130}$ Whilst the story of South

128 Data from World Federation of Exchanges.

129 Armour et al. (2009), supra note 46.

130 Ibid., But note South Africa and Nigeria are both not regarded as having a pure common law system but having a "mixed legal system of Roman-Dutch civil law, English common law, and customary law", and a "mixed legal system of English common law, Islamic law (in 12 northern states), and traditional law" respectively. See CIA, The World Factbook: Legal System (2017), available at: <https://www.cia.gov/library/publications/the-world-factbook/fields/2100. html>, accessed 26 March 2018. 
Table 5: Various features of selected African countries.

\begin{tabular}{lrll}
\hline & Market cap & $\begin{array}{r}\text { Minority } \\
\text { shareholder } \\
\text { protection index }\end{array}$ & Colonial origin \\
\hline South Africa & $>$ \$100bn & 7.0 & British \\
Morocco & $\$ 30-\$ 100 b n$ & French \\
Egypt & $\$ 6-\$ 30$ bn & 4.8 & British \\
BRVM members & 4.0 & Mostly French \\
Kenya & (Côte d'Ivoire) & \\
Mauritius & 5.3 & British \\
Nigeria & 6.5 & British \\
Tunisia & 6.5 & British \\
Botswana & 4.7 & French \\
Ghana & $\$ 1-\$ 6$ bn & 6.0 & British \\
Namibia & 5.3 & British \\
Uganda & 5.5 & German \\
Tanzania & 5.0 & British \\
Zambia & 4.0 & British \\
Zimbabwe & 5.3 & British \\
\hline
\end{tabular}

Sources: PwC, 2016 Africa Capital Markets Watch (2017); World Bank, Doing Business Report 2017 (2017); and Japan Africa Network, African Countries and their Independence Days (2007), available at: <http://www.japanafricanet.com/directory/ presidents/africanindependence.html>, accessed 26 March 2018.

Africa is to be discussed further below, Nigeria had essentially adopted the laws in the UK directly until the first corporate statute was enacted in 1912, and since then the country has continually been influenced by the UK. ${ }^{131}$ For example, the Companies Ordinance 1922 of Nigeria was based on the UK Companies Act of 1929. Likewise, the 1968 law was mainly based on the UK Act of 1948. Meanwhile, it is worth noting from Table 5 that, although Mauritius, with the second best score of 6.5, has a British colonial origin, its legal system is indeed a "civil legal system based on French civil law with some elements of English common law" as influenced by its earlier colonial ruler. ${ }^{132}$ The colonial origin-development nexus

131 For the historical evolution of Nigerian company law, see for example, B. Akinola, "A Critical Appraisal of the Doctrine of Corporate Personality Under the Nigerian Company Law", NLII Working Paper Series 002 (2009), available at: <www.nlii.org/files/NLIIWPS002.pdf>, accessed 26 March 2018; O. Orojo, Company Law and Practice in Nigeria (Lagos: Mbeyi \& Associates, 1992); and B. Ahunwan, Corporate Governance in Nigeria, 37 Journal of Business Ethics, no. 3 (2002), 269-287.

132 CIA (2017), supra note 130. 
in Africa is indeed complex. ${ }^{133}$ Colonialism may have long gone, but the British influence persists. One notable influence is the global concern on corporate governance, arguably triggered by the Cadbury Report in the UK. ${ }^{134}$ According to the European Corporate Governance Institute which makes available the full texts of corporate governance codes, principles of corporate governance and corporate governance reforms around the world, a number of Africa countries have their own corporate governance codes, especially those higher up in Table $5 .^{135}$ According to the Global Financial Centre Index, only Casablanca and Johannesburg, which incidentally are the largest markets in Africa, are featured in the list, illustrating perception from global investors on the two countries' conditions such as institutional and regulatory environment, as better than the rest of Africa. ${ }^{136}$ The following subsections will proceed to look at the legal institutions supporting the markets in specific countries.

\subsection{The Seychelles}

As a former British colony, the Seychelles became independent in 1976. Despite being described as a "mixed legal system of English common law, French civil law, and customary law," the laws of commerce and banking are mainly based on statutes which originated in the common law system. ${ }^{137}$ Local companies are incorporated under the Companies Ordinance 1972, which was recently amended in 2012. ${ }^{138}$ It is worth noting that there is a separate regime governing foreign companies, which are regulated by the International Business Companies Act

133 See Acemoglu et al. (2001), supra note 8; P. Englebert, Pre-Colonial Institutions, PostColonial States, and Economic Development in Tropical Africa, 53 Political Research Quarterly, no. 1 (2000), 7-36; and L. Heldring and J. Robinson, “Colonialism and Development in Africa”, NBER Working Paper 18566 (2012), available at: <www.nber.org/papers/w18566>, accessed 26 March 2018.

134 C. Jordan, Cadbury Twenty Years On, 58 Villanova Law Review, no. 1 (2013), 1-24.

135 See ECGI, Index of All Codes (2017), available at: <http://www.ecgi.org/codes/all_codes.php>, accessed 26 March 2018. With respect to the countries in Table 5, those without a code include BRVM members, Botswana, Ghana, Namibia, Uganda, Tanzania, Zambia and Zimbabwe, mostly bottom of the table.

136 Long Finance, The Global Financial Centres Index (2017), available at: <http://www.long finance.net/programmes/global-financial-centres-index.html>, accessed 26 March 2018.

137 OECD, Global Forum on Transparency and Exchange of Information for Tax Purposes Peer Reviews: The Seychelles 2013 (Paris: OECD, 2013), para. 24.

138 Companies Ordinance (Amendment) Act 2012 is available at: <https://www.seylii.org/sc/ legislation/consolidated-act/40>, accessed 26 March 2018. 
2016 (formerly the International Business Companies Act 1994). ${ }^{139}$ According to the OECD, between 2005 and 2012, the number of international business companies incorporated in Seychelles increased from 25,000 to more than 108,000, making the Seychelles the second jurisdiction in the world after the British Virgin Islands for the number of international business companies incorporated. ${ }^{140}$ This has coincided with the government's commitment to grow the Seychelles as an offshore financial center. ${ }^{141}$ As a stock market which was launched towards the end of 2012 and with only 10 companies currently, there is not much to say about it and its regulation. The legal foundation for the securities exchange had been laid earlier with the passing of the Securities Act 2007. ${ }^{142}$ The Seychelles Financial Services Authority, established under the Financial Services Authority Act 2014, is the regulator of the market. ${ }^{143}$ Listing rules are issued by the exchange, Trop-X. There is not yet a code of corporate governance.

\subsection{South Africa}

Similarly, as a former British colony, South Africa has received much influence from its colonial ruler. ${ }^{144}$ Company law has existed in South Africa since 1861, beginning with the Joint Stock Companies Limited Liabilities Act of 1861 of the Cape Colony which was essentially a mirror of the English Joint Stock Companies Act 1856. The first national company law, the Union Companies Act, was introduced in 1926, which was amended from time to time along the lines of the latest English legislation. The 1926 Act was then replaced by the Companies Act of 1973. South African company law "remains much in the mold of English law."145 The current version is the Companies Act of 2008, replacing the 1973 Act. According to the Department of Trade and Industry, the

139 The Act is available at: <https://www.seylii.org/sc/legislation/act/2016/15>, accessed 26 March 2018.

140 OECD (2013), supra note 137, para. 33.

141 Ibid., para. 32.

142 The Act is available at: <https://www.seylii.org/sc/legislation/act/2007/8>, accessed 26 March 2018.

143 The regulator's website is at: $<$ http://www.fsaseychelles.sc/index.php/about-us $>$, accessed 26 March 2018.

144 South African Government, South African Company Law for the twenty-first Century, Government Gazette Notice 1183 of 2004 (2004).

145 Ibid., p. 12. 
new Act is intended to achieve multiple purposes such as "encouraging transparency and high standards of corporate governance," "balancing the rights and obligations of shareholders and directors in companies" and "encouraging the efficient and responsible management of companies."146 Amongst numerous changes, a notable one is the codification of directors' duties, which is contained in Section 76(3) of the Act. This change is in line with what has been witnessed in the UK. ${ }^{147}$ For simplicity, it may be advisable to refer to various indices to see how the South African company law has fared against other jurisdictions. As said before, with a minority shareholder protection score of 7 given by the World Bank, it is the highest in Africa. Although it is not as good as the top 5 of the world, largely composed of former British colonies such as Singapore and Hong Kong, plus the UK at sixth, it is already better than some advanced economies such as France, Germany, Japan and the US. ${ }^{148}$ A further insight can perhaps be drawn from another dataset charting legal change over time in shareholder protection, prepared by Cambridge's Centre of Business Research. ${ }^{149}$ Of the sample of 30 countries, South Africa is the only one in Africa. The five countries with the biggest increase in shareholder protection over the 24-year period of study between 1990 and 2013 were China $(+7.85)$, Slovenia (+6.88), Russia (+5.6), the Netherlands (+5.5) and Estonia (+5.25). Meanwhile, South Africa has experienced a modest jump $(+1.865)$. This illustrates that South Africa may not have done as good as fellow emerging countries like China and Russia, but it has already fared better against those top countries in 1990, i. e. Malaysia, France, the US, the UK and Japan, which have had a slight increase $(+0.93)$ on average.

As discussed before, investor protection is not only provided by company law, but securities law and listing rules as well. The earliest attempt to regulate the stock market in South Africa was in 1947 when the Stock Exchange Control

146 Department of Trade and Industry South Africa, Notebook on the Companies Act 2008 (2011), available at: <https://www.thedti.gov.za/business_regulation/acts/Companies_Act_ Notebook.pdf>, accessed 26 March 2018.

147 I. Esser and J. Coetzee, Codification of Directors' Duties, 12 Juta's Business Law Review, no. 1 (2004), 26-31. See also ss 171-177 of the Companies Act 2006 of the UK.

148 World Bank (2017), supra note 126.

149 This is available via M. Siems, CBR Extended Shareholder Protection Index (2016), available at: <https://www.repository.cam.ac.uk/bitstream/handle/1810/256566/cbr-spi-30-countriescodebook-and-methodology.pdf?sequence=9\&isAllowed=y>, accessed 26 March 2018. For the interpretation of data, see also D. Katelouzou and M. Siems, Disappearing Paradigms in Shareholder Protection: Leximetric Evidence for 30 Countries, 1990-2013, 15 Journal of Corporate Law Studies, no. 1 (2015), 127-160. 
Act was introduced. ${ }^{150}$ In 2004, the Securities Services Act was enacted to consolidate previous laws relating to the regulation and control of exchanges and securities trading, such as the Stock Exchange Control Act 1985 and the Insider Trading Act 1998. ${ }^{151}$ The current law is the Financial Markets Act of 2012 which replaced the Securities Services Act of 2004. The purpose of this new law is fourfold: to increase market confidence; to promote investor protection; to reduce systemic risk and to promote the international competitiveness of the market. ${ }^{152}$ The importance of it is about alignment. First, it seeks to align financial markets regulation to the Companies Act $2008 .{ }^{153}$ Second, it seeks to ensure that the legislative and regulatory framework is brought in line with the recommendations of international standard setting bodies such as the G20, Financial Stability Board, Basel Committee on Banking Supervision and the International Organization of Securities Commissions. ${ }^{154}$ Further, there are some other efforts from South African government to enhance its stock market. As discussed, foreign firms have been allowed to list on the JSE since 2004. ${ }^{155}$ The 2011 decision to allowed foreign companies to be treated as domestic listings has made the JSE a more attractive destination for foreign listings. The change allowed foreign companies to be treated as domestic listings and therefore the limitations on the amount of foreign equities that local investors could hold were effectively lifted. Also, there have been prominent efforts of enhancing corporate governance in South Africa. ${ }^{156}$ Immediately after the Cadbury Report in the UK in 1992, the Institute of Directors in Southern Africa established in July 1993 the King Committee on Corporate Governance. The King Committee produced the first King Report on Corporate Governance which was published on 29 November 1994. The King Committee on Corporate Governance launched the second report in 2002 and the third report in 2009. Section 8.63 of the JSE

150 Johannesburg Stock Exchange (2017), supra note 69.

151 Preamble and Schedule to Section 117 of the Act.

152 Financial Services Board, Introduction to Financial Markets Act 19 of 2012 (2013), available at: <https://www.fsb.co.za/Departments/capitalMarkets/Documents/Introduction $\% 20$ to\% 20Financial\%20Markets\%20Act\%2019\%20of\%202012.pdf>, accessed 26 March 2018.

153 Linklaters, South African Financial Markets Act, 2012 Enters into Effect (2013), available at: <http://www.linklaters.com/Insights/Publication1386Newsletter/Insurance-Update-July-2013/ Pages/South-African-Financial-Markets-Act-2012-enters-effect.aspx>, accessed 26 March 2018.

154 South African Government News Agency, Financial Markets Act to Come into Effect in June (2013), available at: <http://www.sanews.gov.za/south-africa/financial-markets-act-come-effectjune>, accessed 26 March 2018.

155 See supra note 109 and the accompanying texts above.

156 Institute of Directors Southern Africa, King Report on Corporate Governance in SA (2017), available at: <http://www.iodsa.co.za/?kingIII>, accessed 26 March 2018. 
Listing Rules requires all listed companies to report on the application of the King Report and Code on Corporate Governance. This "comply or explain" approach is yet another example of how South Africa has learned from the UK system. ${ }^{157}$ The JSE is clearly well managed as it has been ranked first out of over 100 countries for regulation of securities exchanges for a number of consecutive years by the World Economic Forum's Global Competiveness Report. ${ }^{158}$

\subsection{Morocco}

As a former French colony, from 1922 until 1997, Moroccan public companies were governed exclusively by French law. ${ }^{159}$ A dahir (Royal Decree) of 1922 applied the relevant provisions of the French commercial statute of 24 July 1867 to Morocco. Towards the end of the last century, the much needed modernization of Moroccan company law came on 2 July 1996. Law 17-95 was adopted, which again mirrored the French company law of 24 July 1966. ${ }^{160}$ It is still the current law in Morocco, as amended in 2008 and 2015. For example, the amendments in 2015 aim to improve the legal framework of public limited companies by fostering greater transparency for listed companies. ${ }^{161}$ There is a separate Law 05-96 for private companies. According to a corporate governance survey undertaken by the OECD in 2005, it highlighted

157 The Cadbury Report was the first time ever that the need for flexibility and experimentation in corporate governance was considered by coming up with the policy of "comply or explain". This policy has had a profound impact on worldwide corporate governance, not just on common law systems. See Financial Reporting Council, Comply or Explain: 20th Anniversary of the UK Corporate Governance Code (2012), p. 8, available at: <https://www.frc.org.uk/OurWork/Publications/Corporate-Governance/Comply-or-Explain-20th-Anniversary-of-the-UKCorpo.aspx>, accessed 26 March 2018.

158 African Markets, South Africa: Stock Exchange Ranked \#1 in Regulation of Securities Exchanges (2013), available at: <https://www.african-markets.com/en/stock-markets/jse/southafrica-stock-exchange-ranked-1-in-regulation-of-securities-exchanges>, accessed 26 March 2018. But it fell to second and third in the 2015-2016 and 2016-2017 reports, respectively.

159 S. Quinn, "Moroccan Company Law Reform and Manufacturing Firms' Access to Manufacturing Firms' Access to Bank Credit: A Before/After Panel Evaluation”, Oxford University Economics Working Paper (2009), available at: <https://www.csae.ox.ac.uk/confer ences/2009-EdiA/papers/103-Quinn.pdf>, accessed 26 March 2018.

160 Ibid.

161 Law 78-12. See also Eversheds Sutherland, Morocco: More Transparency for Public Limited Companies (2016), available at: <http://www.eversheds-sutherland.com/global/en/what/arti cles/index.page?ArticleID=en/Africa_group/transparency-Public-Limited-Companies>, accessed 26 March 2018. 
the fact that due to the limited number of listed companies (54 at that time; 75 now in 2017), banks had a key role in promoting good corporate governance as opposed to the market. ${ }^{162}$ Fast forward 10 years to look at a report by the European Bank for Reconstruction and Development, on the one hand, it praised the adoption of a Corporate Governance Code in 2008 by the National Corporate Governance Commission, which took into account of the OECD's Principles of Corporate Governance. ${ }^{163}$ On the other hand, the code is merely providing a set of recommendations and exists in isolation that the listing rules do not require companies to comply with the Code, not even on a "comply or explain" basis. ${ }^{164}$ This echoes its minority shareholder protection score of 5.3 given by the World Bank, which is mediocre. In terms of securities regulation, the first comprehensive reform was witnessed in 1967, almost four decades after the stock market had been established. ${ }^{165}$ As of today, key laws in this area include Law 1-93-211 relating to the Stock Exchange, Law 1-13-21 relating to the L'Autorité Marocaine du Marché des Capitaux (AMMC; formerly Conseil Déontologique des Valeurs Mobilières, CDVM until 2016) as the market regulator and information required of corporate entities making a public share offering and Law 26-03 relating to public offerings. According to the OECD, the investigation and sanction powers of the regulatory authority (CDVM at that time) should mean it has the capacity to fulfil its duties in a professional and objective manner. ${ }^{166}$

\subsection{Egypt}

A fairly poor shareholder protection score of 4.8 given by World Bank should presumably present a pessimistic picture about the situation in Egypt. The two crucial pieces of legislation in Egypt in the context of this article are the Company Law of 1981 and the Capital Market Law of 1992, together with the

162 OECD, Corporate Governance Survey: Morocco 2005 (2005), available at: <http://www.oecd. org/corporate/ca/corporategovernanceprinciples/34921128.pdf>, accessed 26 March 2018.

163 European Bank for Reconstruction and Development, Corporate Governance in Transition Economies Morocco Country Report (2016), available at: <http://www.ebrd.com/documents/ogc/ morocco.pdf>, accessed 26 March 2018.

164 Ibid.

165 Bourse de Casablanca, History (2012), available at: <http://www.casablanca-bourse.com/ bourseweb/en/content.aspx?IdLink=201\&Cat=1>, accessed 26 March 2018.

166 OECD (2005), supra note 162. 
Corporate Governance Code of 2016. ${ }^{167}$ Before these laws, in the beginning of the twentieth century, Egyptian joint stock companies could only be incorporated by a Khedivial Decree (Article 46 of the Mixed Code of Commerce and Article 40 of the Native Code of Commerce). ${ }^{168}$ The first Commercial Code in Egypt was promulgated in 1883 by French lawyers. ${ }^{169}$ In 1947, the Company Law was passed by the Egyptian Parliament, which was intended to increase the participation of Egyptians in business, thereby causing foreign discontent. ${ }^{170}$ In relation to the Capital Market Law, its predecessor was the Stock Exchange Law of 1957. One important point of the legal change in 1992 was the introduction of Capital Market Authority (CMA; now Egyptian Financial Supervisory Authority, EFSA). The Corporate Governance Code was first adopted in 2005 and then revised twice in 2011 and 2016.

According to the assessment by the European Bank for Reconstruction and Development, there are certain notable shortfalls in the Egyptian system. ${ }^{171}$ As for the corporate governance code generally, pretty much like Morocco, the compliance is entirely voluntary. Only two of the ten largest listed companies provided a "comply or explain" section with their annual reports. ${ }^{172}$ The code's effectiveness would be greatly increased if its application were required for listed companies under the "comply or explain" basis. This means that although the Corporate Governance Code, for example, recommends that boards should be comprised of a majority of independent non-executive members, audit committees seem to lack the necessary independence to make them effective. ${ }^{173}$ Furthermore, corporate transparency remains problematic. ${ }^{174}$ As reported by the World Bank, both financial and non-financial information of listed

167 Baker \& McKenzie, Doing Business in Egypt (2016), available at: <http://www.bakermcken zie.com/-/media/files/insight/publications/2016/03/bk_egypt_dbi_2016.pdf?la=en>, accessed 26 March 2018.

168 M. Mcllwraith, The Status of British Companies in Egypt, 12 Journal of the Society of Comparative Legislation, no. 1 (1911), 85-94.

169 D. Wilson, A New Commercial Code for Egypt, 6 Yearbook of Islamic and Middle Eastern Law, no. 1 (1999), 87-119; and I. Edge, Comparative Commercial Law of Egypt and the Arabian Gulf, 34 Cleveland State Law Review, no. 1 (1985), 129-144.

170 R. Tignor, Capitalism and Nationalism at the End of Empire (Princeton: Princeton University Press, 1997), p. 36 and CIA, The Current Situation in Egypt (1947), available at: <https://www.cia. gov/library/readingroom/docs/DOC_0000256627.pdf>, accessed 26 March 2018.

171 European Bank for Reconstruction and Development, Commercial Laws of Egypt (2012), available at: <http://www.ebrd.com/downloads/sector/legal/egypt.pdf>, accessed 26 March 2018.

172 Ibid., p. 17.

173 Ibid., p. 5.

174 N. Shehata and K. Dahawy, 2013 Review of the Implementation Status of Corporate Governance Disclosures: Egypt, UNCTAD-ISAR 30th Annual Session Working Paper (2013), 
companies is not easily accessible by investors. ${ }^{175}$ However, the Egyptian market still has the strength of a high institutional investor participation rate (close to 30 per cent) over illiquid markets such as Morocco. ${ }^{176}$ Institutional investors can fill the void left by inadequate rules and play a monitoring role. ${ }^{177}$

\section{Conclusion}

Research has long emphasized the important of institutions to economic growth. It is safe to assume that Africa, as the most underdeveloped part of the world, lack those institutions. In general, this is true. The only notable financial market in Africa is South Africa. The others are almost negligible globally. Worryingly, most Africa countries, again with the exception of South Africa, do not have a welldeveloped banking system to fill the void of a stock market as the institution to channel national capital to the entrepreneurs. Apparently, by having a strong banking sector and a vibrant stock market, it can be assumed that South Africa must be the most developed country in the region. Unfortunately, it is not true. The Seychelles is the wealthiest country in Africa. It has neither of the strengths of South Africa. The banks there have not channelled enough capital to the private sector to foster economic growth. Its stock market is very new with just 10 listed companies at the moment. Considering the story of the Seychelles, finance apparently is not essential for prosperity. Of course, the caveat here is, the Seychelles can simply be an exception. Further, looking at Morocco and Egypt, despite having the largest stock markets (just behind South Africa), they are indeed not the wealthiest in the region. There are eight more African countries above them, in addition to the Seychelles and South Africa, in the high-income and

available at: <http://unctad.org/meetings/en/Presentation/ciiisar30_811_2EgyptReport.pdf>, accessed 26 March 2018.

175 World Bank, The Arab Republic of Egypt - Report on the Observance of Standards and Codes (ROSC): Corporate Governance Country Assessment, ROSC Report (2009), available at: <http:// documents.worldbank.org/curated/en/348141468247498839/The-Arab-Republic-of-EgyptReport-on-the-Observance-of-Standards-and-Codes-ROSC-corporate-governance-country-assess ment>, accessed 26 March 2018.

176 OECD, "What Role for MENA Stock Exchanges in Corporate Governance?”, Discussion Paper (2011), available at: 〈http://www.oecd.org/corporate/ca/48897794.pdf〉, accessed 26 March 2018.

177 J. Coffee, Liquidity versus Control: The Institutional Investor as Corporate Monitor, 91 Columbia Law Review, no. 6 (1991), 1277-1368; and B. Black and J. Coffee, Hail Britannia?: Institutional Investor Behavior under Limited Regulation, 92 Michigan Law Review, no. 1 (1994), 1997-2087. 
upper-middle-income categories when Morocco and Egypt are just lower-middleincome economies according to the World Bank's benchmarks.

Turning to the legal factors, first looking at Africa as a whole, the inadequacy of shareholder protection overall in the region fits well with the fact that the continent is quite backward in both economic and financial development. Law indeed can explain the growth stories of both the Seychelles and South Africa. The Seychelles may not have the deepest financial sector; however, it is capable of attracting a lot of foreign companies to incorporate there. It, as a former British colony, is apparently developing along the line of other common law tax havens such as the British Virgin Islands, Bermuda and the Cayman. South Africa also sits well with the idea that common law is capable of providing superior shareholder protection, thereby making people feel more comfortable to invest in equity. Of course, a counterargument can be the question of why Morocco and Egypt, by having an essentially Napoleonic civil law system, can have a more vibrant financial sector than other common law countries in Africa. One convenient explanation is, the exchanges in Egypt, Morocco and South Africa are incidentally the oldest in Africa. It can be just about the time they have existed, thereby building up a trusted brand name. Another point is, indeed Nigeria is not too far behind Egypt by having the fourth largest exchange in the region. The common law advantage is not absolute but can still be true. This perhaps points us back to the beginning of this article that there is a need to examine a package of institutional factors, ${ }^{178}$ such as law, finance, politics, trade, culture, technology, education, and colonial origin to provide a more convincing and comprehensive account of growth. Relying on one or two of them, like law and finance only in this article, is often inconclusive. This article hopes to open further debate on ways to explore this topic, no matter in the context of Africa or other regions. ${ }^{179}$

\section{References}

Acemoglu, D., Introduction to Modern Economic Growth (Princeton: Princeton University Press, 2009). Acemoglu, D., S. Johnson and J. Robinson, The Colonial Origins of Comparative Development:

An Empirical Investigation, 91 American Economic Review, no. 5 (2001).

178 See supra notes 1-8.

179 For example, a wider array of institutional factors has been examined in the context of Asia, see F. Huang and H. Yeung, Institutions and Economic Growth in Asia (Abingdon: Routledge, 2018). Singapore has devoted considerable efforts in strengthening their institutional advantages, which convincingly explain why it has one of the highest GDP per capita in Southeast Asia, only behind Macau (arguably an exceptional case benefiting solely from the gambling sector). 
Acemoglu, D., S. Johnson and J. Robinson, Reversal of Fortune: Geography and Institutions in the Making of the Modern World Income Distribution, 117 Quarterly Journal of Economics, no. 4 (2002).

Acemoglu, D. and J. Ventura, The World Income Distribution, 107 Quarterly Journal of Economics, no. 2 (2002).

African Development Bank, Seychelles Economic Outlook (2017a), available at: <https://www. afdb.org/en/countries/east-africa/seychelles/seychelles-economic-outlook/>, accessed 26 March 2018.

African Development Bank, South Africa Economic Outlook (2017b), available at: <https://www. afdb.org/en/countries/southern-africa/south-africa/south-africa-economic-outlook/>, accessed 26 March 2018.

African Development Bank, Morocco Economic Outlook (2017c), available at: <https://www. afdb.org/en/countries/north-africa/morocco/morocco-economic-outlook/>, accessed 26 March 2018.

African Development Bank, Egypt Economic Outlook (2017d), available at: <https://www.afdb. org/en/countries/north-africa/egypt/egypt-economic-outlook/>, accessed 26 March 2018.

African Development Bank and OECD, African Economic Outlook (Abidjan: African Development Bank and OECD, 2003), available at: <https://www.oecd.org/countries/morocco/2497527. pdf>, accessed 26 March 2018.

African Leadership Magazine, Ethiopia: Largest Country in the World without a Stock Exchange (2015), available at: <http://africanleadership.co.uk/ethiopia-largest-country-in-the-worldwithout-a-stock-exchange>, accessed 26 March 2018.

African Markets, South Africa: Stock Exchange Ranked \#1 in Regulation of Securities Exchanges (2013), available at: <https://www.african-markets.com/en/stock-markets/jse/south-africastock-exchange-ranked-1-in-regulation-of-securities-exchanges>, accessed 26 March 2018.

Agencia Angola Press, Angola Stock Exchange May Play Strategic Role in SADC (2017), available at: <http://www.angop.ao/angola/en_us/noticias/economia/2017/2/11/Angola-StockExchange-may-play-strategic-role-SADC,f9423b85-4a9c-4008-951a-0674cb75d222.html>, accessed 26 March 2018.

Ahunwan, B., Corporate Governance in Nigeria, 37 Journal of Business Ethics, no. 3 (2002).

Akinola, B., A Critical Appraisal of the Doctrine of Corporate Personality under the Nigerian Company Law, NLII Working Paper Series 002 (2009), available at: <www.nlii.org/files/ NLIIWPS002.pdf>, accessed 26 March 2018.

Algerian Stock Exchange, SGBV (2017), available at: <http://www.sgbv.dz/?page=rubrique\& lang=eng\&mod=116>, accessed 26 March 2018.

Allen, F. and D. Gale, Comparing Financial Systems (Cambridge: MIT Press, 2000).

Allen, F., I. Otchere and L. Senbet, African Financial Systems: A Review, 1 Review of Development Finance, no. 2 (2011).

Allen, F., J. Qian and M. Qian, Law, Finance, and Economic Growth in China, 77 Journal of Financial Economics, no. 1 (2005).

ALTX East Africa Exchange, About Us (2017), available at: <https://www.altxafrica.com/aboutaltx>, accessed 26 March 2018.

Arestis, P., P. Demetriades and K. Luintel, Financial Development and Economic Growth:

The Role of Stock Markets, 33 Journal of Money, Credit and Banking, no. 1 (2001).

Armour, J. et al., Principles of Financial Regulation (Oxford: OUP, 2016).

Armour, J. et al., Anatomy of Corporate Law (Oxford: OUP, 2017). 
Armour, J., S. Deakin, P. Sarkar, M. Siems and A. Singh, Shareholder Protection and Stock Market Development: An Empirical Test of the Legal Origins Hypothesis, 6 Journal of Empirical Legal Studies, no. 2 (2009).

ASEA, Membership: Introduction (2017), available at: <http://www.african-exchanges.org/en/ membership\#contentCarousel/introduction>, accessed 26 March 2018.

Atje, R. and B. Jovanovic, Stock Markets and Development, 37 European Economic Review, no. 2-3 (1993).

Baker \& McKenzie, Doing Business in Egypt (2016), available at: <http://www.bakermckenzie. com/-/media/files/insight/publications/2016/03/bk_egypt_dbi_2016.pdf?la=en>, accessed 26 March 2018.

Barro, R., Determinants of Democracy, 107 Journal of Political Economy, no. 6 (1999).

Bartelsman, E. and M. Doms, Understanding Productivity: Lessons from Longitudinal Microdata, 38 Journal of Economic Literature, no. 3 (2000).

BBC, Is Kofi Annan Pulling His Weight for Africa? (2000), available at: <http://news.bbc.co.uk/ 1/hi/talking_point/debates/african/677098.stm>, accessed 26 March 2018.

Beck, T. and R. Levine, "Legal Institutions and Financial Development”, in C. Menard and M. Shirley (eds.), Handbook of New Institutional Economics (Dordrecht: Springer, 2005).

Berkowitz, D., K. Pistor and J. Richard, Economic Development, Legality and the Transplant Effect, 47 European Economic Review, no. 1 (2003).

Black, B., The Legal and Institutional Preconditions for Strong Securities Markets, 48 UCLA Law Review, no. 4 (2001).

Black, B. and J. Coffee, Hail Britannia?: Institutional Investor Behavior under Limited Regulation, 92 Michigan Law Review, no. 1 (1994).

Black, B. and R. Gilson, Does Venture Capital Require an Active Stock Market?, 11 Journal of Applied Corporate Finance, no. 4 (1999).

BofA Merrill Lynch, Transforming World Atlas (2016), available at: <https://www.bofaml.com/ content/dam/boamlimages/documents/articles/ID16-305/bofaml_transforming_world_ atlas_2nd_edition.pdf>, accessed 26 March 2018.

Bourse de Casablanca, History (2012), available at: <http://www.casablanca-bourse.com/bour seweb/en/content.aspx?IdLink=201\&Cat=1>, accessed 26 March 2018.

Caporale, G., P. Howells and A. Soliman, Stock Market Development and Economic Growth: The Causal Linkage, 29 Journal of Economic Development, no. 1 (2004).

Carlin, W. and C. Mayer, Finance, Investment and Growth, 69 Journal of Financial Economics, no. 1 (2003).

Central Bank of Seychelles, Annual Report 2016 (2017), available at: <http://www.cbs.sc/ Downloads/publications/Annual\%20Report\%202016.pdf>, accessed 26 March 2018.

Cheffins, B., Does Law Matter?: The Separation of Ownership and Control in the United Kingdom, 30 Journal of Legal Studies, no. 2 (2001).

Chutel, L., "South Africa May Get Three More Stock Exchanges - And a Lot More Investors", Quartz, 18 April 2016, available at: <https://qz.com/662054/south-africa-may-get-threemore-stock-exchanges-and-a-lot-more-investors/>, accessed 26 March 2018.

CIA, The Current Situation in Egypt (1947), available at: <https://www.cia.gov/library/readin groom/docs/DOC_0000256627.pdf>, accessed 26 March 2018.

CIA, The World Factbook: Legal System (2017), available at: <https://www.cia.gov/library/pub lications/the-world-factbook/fields/2100.html>, accessed 26 March 2018. 
Claessens, S., S. Djankov and D. Klingebiel, “Stock Markets in Transition Economies”, (2000), Financial Sector Discussion Paper No. 5, available at: <http://ssrn.com/abstract=240703>, accessed 26 March 2018.

Claessens, S., N. Van Horen, T. Gurcanlar and J. Sapiain, "Foreign Bank Presence in Developing Countries 1995-2006: Data and Trends", (2008), World Bank Working Paper, available at: <https://ssrn.com/abstract=1107295〉, accessed 26 March 2018.

Coffee, J., Liquidity versus Control: The Institutional Investor as Corporate Monitor, 91 Columbia Law Review, no. 6 (1991).

Coffee, J., The Rise of Dispersed Ownership the Roles of Law and the State in the Separation of Ownership and Control, 111 Yale Law Journal, no. 1 (2001).

Coffee, J., Law and the Market: The Impact of Enforcement, 156 University of Pennsylvania Law Review, no. 2 (2007).

Cotterill, J., "Fitch Cuts South Africa's Credit Rating to Junk", Financial Times, 7 April 2017.

Dam, K., The Law-Growth Nexus (Washington, DC: Brookings, 2006).

Demirguc-Kunt, A. and R. Levine, Stock Markets, Corporate Finance and Economic Growth: An Overview, 10 World Bank Economic Review, no. 2 (1996).

Department of Commerce US, South Africa - Banking Systems (2016), available at: <https:// www.export.gov/article?id=South-Africa-banking-systems>, accessed 26 March 2018.

Department of Commerce US, Egypt - Banking Systems (2017), available at: <https://www. export.gov/article?id=Egypt-Banking-Systems>, accessed 26 March 2018.

Department of Foreign Affairs of the Seychelles, Seychelles Graduates to High-Income Country Status according to World Bank Standards (2015), available at: <http://www.mfa.gov.sc/ static.php?content_id=18\&news_id=1071>, accessed 26 March 2018.

Department of Trade and Industry South Africa, Notebook on the Companies Act 2008 (2011), available at: <https://www.thedti.gov.za/business_regulation/acts/Companies_Act_ Notebook.pdf>, accessed 26 March 2018.

Easterly, W. and R. Levine, Africa's Growth Tragedy: Policies and Ethnic Divisions, 112 Quarterly Journal of Economics, no. 4 (1997).

ECGI, Index of All Codes (2017), available at: 〈http://www.ecgi.org/codes/all_codes.php>, accessed 26 March 2018.

Edge, I., Comparative Commercial Law of Egypt and the Arabian Gulf, 34 Cleveland State Law Review, no. 1 (1985).

Egyptian Stock Exchange, History (2017), available at: <http://www.egx.com.eg/english/ History.aspx>, accessed 26 March 2018.

Englebert, P., Pre-Colonial Institutions, Post-Colonial States, and Economic Development in Tropical Africa, 53 Political Research Quarterly, no. 1 (2000).

Esser, I. and J. Coetzee, Codification of Directors' Duties, 12 Juta's Business Law Review, no. 1 (2004).

European Bank for Reconstruction and Development, Commercial Laws of Egypt (2012), available at: <http://www.ebrd.com/downloads/sector/legal/egypt.pdf>, accessed 26 March 2018.

European Bank for Reconstruction and Development, Corporate Governance in Transition Economies Morocco Country Report (2016), available at: <http://www.ebrd.com/docu ments/ogc/morocco.pdf>, accessed 26 March 2018.

Eversheds Sutherland, Morocco: More Transparency for Public Limited Companies (2016), available at: <http://www.eversheds-sutherland.com/global/en/what/articles/index. page?ArticleID=en/Africa_group/transparency-Public-Limited-Companies>, accessed 26 March 2018. 
Fama, E., Efficient Capital Markets: A Review of Theory and Empirical Work, 25 Journal of Finance, no. 2 (1970).

Financial Reporting Council, Comply or Explain: 20th Anniversary of the UK Corporate Governance Code (2012), available at: <https://www.frc.org.uk/Our-Work/Publications/ Corporate-Governance/Comply-or-Explain-20th-Anniversary-of-the-UK-Corpo.aspx>, accessed 26 March 2018.

Financial Services Board, Introduction to Financial Markets Act 19 of 2012 (2013), available at: <https://www.fsb.co.za/Departments/capitalMarkets/Documents/Introduction\%20to\% 20Financial\%20Markets\%20Act\%2019\%20of\%202012.pdf>, accessed 26 March 2018.

Financial Times, Definition of Frontier Markets (2017), available at: <http://lexicon.ft.com/Term? term=frontier-markets\&mhq5j=e2>, accessed 26 March 2018.

Gullifer, L. and J. Payne, Corporate Finance Law: Principles and Policy (Oxford: Hart, 2015).

Gumede, A. and A. Mbatha, The Charts That Show South Africa's Unemployment Problem (2017), available at: <https://www.bloomberg.com/news/articles/2017-06-01/south-africa-job less-rate-rises-to-14-year-high-in-first-quarter>, accessed 26 March 2018.

Hamilton, W., The Institutional Approach to Economic Theory, 9 American Economic Review, no. 1 (1919).

Harris, R., Stock Markets and Development: A Re-Assessment, 41 European Economic Review, no. 1 (1997).

Heldring, L. and J. Robinson, "Colonialism and Development in Africa", NBER Working Paper 18566 (2012), available at: 〈www.nber.org/papers/w18566〉, accessed 26 March 2018.

Hodgson, G., What Is the Essence of Institutional Economics?, 34 Journal of Economic Issues, no. 2 (2000).

Hodgson, G., What Are Institutions?, 40 Journal of Economic Issues, no. 1 (2006).

Huang, F. and H. Yeung, Institutions and Economic Growth in Asia (Abingdon: Routledge, 2018). IMF, Seychelles: Recent Economic Developments, Country Report No. 00/162 (2000), para. 32, available at: 〈https://www.imf.org/external/pubs/ft/scr/2000/cr00162.pdf>, accessed 26 March 2018.

IMF, Morocco: Financial System Stability Assessment, Country Report No. 16/37 (2016), available at: <https://www.imf.org/en/Publications/CR/Issues/2016/12/31/Morocco-FinancialSystem-Stability-Assessment-43676>, accessed 26 March 2018.

Institute of Directors Southern Africa, King Report on Corporate Governance in SA (2017), available at: 〈http://www.iodsa.co.za/?kinglll>, accessed 26 March 2018.

Investment Frontier, List of Countries without Stock Exchanges (2014), available at: <https:// www.investmentfrontier.com/2014/07/28/list-countries-without-stock-exchanges>, accessed 26 March 2018.

Irving, J., Africa's Struggling Stock Exchanges, 14 Africa Recovery, no. 3 (2000).

Jackson, H. and M. Roe, Public and Private Enforcement of Securities Laws: Resource-Based Evidence, 93 Journal of Financial Economics, no. 2 (2009).

Japan Africa Network, African Countries and Their Independence Days (2007), available at: <http://www.japanafricanet.com/directory/presidents/africanindependence.html〉, accessed 26 March 2018.

Johannesburg Stock Exchange, JSE Overview (2017a), available at: <https://www.jse.co.za/ about/history-company-overview>, accessed 26 March 2018.

Johannesburg Stock Exchange, Find an Equity Issuer (2017b), available at: <https://www.jse.co. za/current-companies/companies-and-financial-instruments>, accessed 26 March 2018.

Jordan, C., Cadbury Twenty Years On, 58 Villanova Law Review, no. 1 (2013). 
Katelouzou, D. and M. Siems, Disappearing Paradigms in Shareholder Protection: Leximetric Evidence for 30 Countries, 1990-2013, 15 Journal of Corporate Law Studies, no. 1 (2015).

King, R. and R. Levine, Finance and Growth: Schumpeter Might Be Right, 108 Quarterly Journal of Economics, no. 3 (1993).

Klerman, D., P. Mahoney, H. Spamann and M. Weinstein, Legal Origin or Colonial History?, 3 Journal of Legal Analysis, no. 2 (2011).

La Porta, R., F. Lopez-de-Silane and A. Shleifer, What Works in Securities Laws?, 61 Journal of Finance, no. 1 (2006).

La Porta, R., F. Lopez-de-Silane and A. Shleifer, The Economic Consequences of Legal Origins, 46 Journal of Economic Literature, no. 2 (2008).

La Porta, R., F. Lopez-de-Silane, A. Shleifer and R. Vishny, Legal Determinants of External Finance, 52 Journal of Finance, no. 3 (1997).

La Porta, R., F. Lopez-de-Silane, A. Shleifer and R. Vishny, Law and Finance, 106 Journal of Political Economy, no. 6 (1998).

La Porta, R., F. Lopez-de-Silane, A. Shleifer and R. Vishny, Investor Protection and Corporate Governance, 58 Journal of Financial Economics, no. 1-2 (2000).

Lee, Y., General Theory of Law and Development, 50 Cornell International Law Journal, no. 3 (2017).

Levine, R., Law, Finance, and Economic Growth, 8 Journal of Financial Intermediation, no. 1-2 (1999).

Levine, R. and S. Zervos, Stock Market Development and Long-Run Growth, 10 World Bank Economic Review, no. 2 (1996).

Linklaters, South African Financial Markets Act, 2012 Enters into Effect (2013), available at: <http://www.linklaters.com/Insights/Publication1386Newsletter/Insurance-Update-July2013/Pages/South-African-Financial-Markets-Act-2012-enters-effect.aspx>, accessed 26 March 2018.

Long Finance, The Global Financial Centres Index (2017), available at: <http://www.longfinance. net/programmes/global-financial-centres-index.html>, accessed 26 March 2018.

MacNeil, I. and A. Lau, International Corporate Regulation: Listing Rules and Overseas Companies, 50 International and Comparative Law Quarterly, no. 4 (2001).

Mankiw, N.G., D. Romer and D. Weil, A Contribution to the Empirics of Economic Growth, 107 Quarterly Journal of Economics, no. 2 (1992).

Mcllwraith, M., The Status of British Companies in Egypt, 12 Journal of the Society of Comparative Legislation, no. 1 (1911).

McKinnon, R., Money and Capital in Economic Development (Washington, DC: Brookings, 1973).

Michaelson, R., "Egypt's Economy Is in Crisis. So Why Is the Government Spending Millions on a Fancy New Space Agency?", Newsweek, 28 February 2017, available at: <http://www. newsweek.com/2017/03/10/egypts-economy-crisis-government-spending-millions-newspace-agency-561743.html>, accessed 26 March 2018.

Modigliani, F. and E. Perotti, Protection of Minority Interest and the Development of Security Markets, 18 Managerial and Decision Economics, no. 7-8 (1994).

Moody's, Moody's Downgrades the Five Largest South African Banks to Baa3; Outlook Negative (2017), available at: 〈https://www.moodys.com/research/Moodys-downgrades-the-fivelargest-South-African-banks-to-Baa3-PR_367888>, accessed 26 March 2018.

MSCl, Market Classification (2017), available at: 〈https://www.msci.com/market-classification〉, accessed 26 March 2018. 
Nigerian Stock Exchange, Corporate Overview (2017), available at: <http://www.nse.com.ng/ about-us/about-the-nse/corporate-overview>, accessed 26 March 2018.

North, D., Institutions, Institutional Change and Economic Performance (Cambridge: CUP, 1990).

Nyantakyi, E. and M. Sy, The Banking System in Africa: Main Facts and Challenges, 6 Africa Economic Brief, no. 5 (2015).

OECD, Corporate Governance Survey: Morocco 2005 (2005), available at: <http://www.oecd. org/corporate/ca/corporategovernanceprinciples/34921128.pdf>, accessed 26 March 2018.

OECD, "What Role for MENA Stock Exchanges in Corporate Governance?," Discussion Paper (2011), available at: <http://www.oecd.org/corporate/ca/48897794.pdf〉, accessed 26 March 2018.

OECD, Global Forum on Transparency and Exchange of Information for Tax Purposes Peer Reviews: The Seychelles 2013 (Paris: OECD, 2013).

Orojo, O., Company Law and Practice in Nigeria (Lagos: Mbeyi \& Associates, 1992).

Posner, R., Creating a Legal Framework for Economic Development, 13 World Bank Observer, no. 1 (1998).

Przeworski, A. and F. Limongi, Political Regimes and Economic Growth, 7 Journal of Economic Perspectives, no. 3 (1993).

PwC, 2016 Africa Capital Markets Watch (2017), available at: <https://www.pwc.co.za/en/ assets/pdf/africa-capital-markets-watch-2016.pdf>, accessed 26 March 2018.

Quinn, S., “Moroccan Company Law Reform and Manufacturing Firms' Access to Manufacturing Firms' Access to Bank Credit: A Before/After Panel Evaluation”, Oxford University Economics Working Paper (2009), available at: <https://www.csae.ox.ac.uk/conferences/ 2009-EdiA/papers/103-Quinn.pdf>, accessed 26 March 2018.

Reuters, Moroccan Government Drafts New Rules to Attract Stock Market Investors (2015), available at: <http://www.reuters.com/article/morocco-market-idUSL5N11H29220150911>, accessed 26 March 2018.

Reuters, Morocco Opens First Islamic Bank Branch Months after Approval (2017), available at: <http://www.reuters.com/article/morocco-banks-idUSL8N1IP6CO〉, accessed 26 March 2018.

Roe, M., Legal Origins, Politics and Modern Stock Markets, 120 Harvard Law Review, no. 2 (2006).

Romano, R., Empowering Investors: A Market Approach to Securities Regulation, 107 Yale Law Journal, no. 8 (1998).

Rossouw, J., "Why the Johannesburg Stock Exchange Knows What Rivalry Is All About”, The Conversation, 31 March 2016, available at: <https://theconversation.com/why-the-johan nesburg-stock-exchange-knows-what-rivalry-is-all-about-57076>, accessed 26 March 2018.

Rutherford, M., Institutional Economics: Then and Now, 15 Journal of Economic Perspectives, no. 3 (2001).

Schumpeter, J., The Theory of Economic Development (Cambridge: Harvard University Press, 1959).

Shehata, N. and K. Dahawy, "2013 Review of the Implementation Status of Corporate Governance Disclosures: Egypt”, UNCTAD-ISAR 30th Annual Session Working Paper (2013), available at: <http://unctad.org/meetings/en/Presentation/ciiisar30_811_2EgyptReport.pdf〉, accessed 26 March 2018.

Siems, M., Legal Origins: Reconciling Law \& Finance and Comparative Law, 52 McGill Law Journal, no. 1 (2007). 
Siems, M., CBR Extended Shareholder Protection Index (2016), available at: <https://www. repository.cam.ac.uk/bitstream/handle/1810/256566/cbr-spi-30-countries-codebook-andmethodology.pdf?sequence=9\&isAllowed=y>, accessed 26 March 2018.

Snyder, F., The Failure of Law and Development, Wisconsin Law Review [1982].

Somali Stock Exchange, About Us (2017), available at: <http://www.somalistockexchange.so/ about-us>, accessed 26 March 2018.

South African Government, South African Company Law for the twenty-first Century, Government Gazette Notice 1183 of 2004 (2004).

South African Government News Agency, Financial Markets Act to Come into Effect in June (2013), available at: <http://www.sanews.gov.za/south-africa/financial-markets-act-comeeffect-june>, accessed 26 March 2018.

Spamann, H., The "Antidirector Rights Index" Revisited, 23 Review of Financial Studies, no. 2 (2010).

Statistics South Africa, The South African Economy Shrinks by $0.7 \%$ (2017a), available at: <http://www.statssa.gov.za/?p=9989>, accessed 26 March 2018.

Statistics South Africa, The Economy of South Africa (2017b), available at: <http://www.statssa. gov.za/?page_id=595>, accessed 26 March 2018.

Tamanaha, B., The Lessons of Law-and-Development Studies, 89 American Journal of International Law, no. 2 (1995).

Tignor, R., Capitalism and Nationalism at the End of Empire (Princeton: Princeton University Press, 1997).

Trubek, D., "Law and Development 50 Years On (2012)", University of Wisconsin Legal Studies Research Paper no. 1212, available at: 〈http://ssrn.com/abstract=2161899〉, accessed 26 March 2018.

Trubek, D. and M. Galanter, Scholars in Self-Estrangement: Some Reflections on the Crisis in Law and Development Studies in the United States, Wisconsin Law Review [1974].

Uganda Securities Exchange, Background (2017), available at: <https://www.use.or.ug/con tent/background>, accessed 26 March 2018.

United Nations, Secretary-General's Report on the Causes of Conflict and the Promotion of Durable Peace and Sustainable Development in Africa, Report A/52/871-S/1998/318 (1998).

United Nations, Handbook on the Least Developed Country Category: Inclusion, Graduation and Special Support Measures (New York: United Nations, 2015).

United Nations, United Nations Regional Groups of Member States (2017), available at: <http:// www.un.org/depts/DGACM/RegionalGroups.shtml>, accessed 26 March 2018.

United Nations Committee for Development Policy, List of Least Developed Countries (As of June 2017) (2017), available at: <https://www.un.org/development/desa/dpad/wp-content/ uploads/sites/45/publication/ldc_list.pdf>, accessed 26 March 2018.

US Aid, Egypt: Economic Growth and Tourism (2016), available at: <https://www.usaid.gov/ egypt/economic-growth-and-tourism>, accessed 26 March 2018.

Veblen, T., The Theory of the Leisure Class: An Economic Study of Institutions (New York: Macmillan, 1899), available at: <http://moglen.law.columbia.edu/LCS/theoryleisureclass. pdf>, accessed 26 March 2018.

Wilson, D., A New Ocommercial Code for Egypt, 6 Yearbook of Islamic and Middle Eastern Law, no. 1 (1999).

World Bank, The Arab Republic of Egypt - Report on the Observance of Standards and Codes (ROSC): Corporate Governance Country Assessment, ROSC Report (2009), available at: 
<http://documents.worldbank.org/curated/en/348141468247498839/The-Arab-Republicof-Egypt-Report-on-the-Observance-of-Standards-and-Codes-ROSC-corporate-governancecountry-assessment>, accessed 26 March 2018.

World Bank, Access to Finance and Economic Growth in Egypt (Washington, DC: World Bank, 2010), available at: <http://siteresources.worldbank.org/INTEGYPT/Resources/Access_to_ Finance.pdf>, accessed 26 March 2018.

World Bank, World Bank Country and Lending Groups (2017a), available at: <https://datahelp desk.worldbank.org/knowledgebase/articles/906519-world-bank-country-and-lendinggroups>, accessed 26 March 2018.

World Bank, Seychelles: Overview (2017b), available at: <http://www.worldbank.org/en/coun try/seychelles/overview>, accessed 26 March 2018.

World Bank, Doing Business Report 2017 (2017c), available at: <http://www.doingbusiness. org>, accessed 26 March 2018. 